Article

\title{
A Plethora of Epigenetic Minerals Reveals a Multistage Metasomatic Overprint of a Mantle Orthopyroxenite from the Udachnaya Kimberlite
}

\author{
Dmitriy I. Rezvukhin ${ }^{1, *(\mathbb{D}}$, Taisia A. Alifirova ${ }^{1,2} \mathbb{D}$, Alexander V. Golovin ${ }^{1}$ and \\ Andrey V. Korsakov ${ }^{1}$ (D) \\ 1 Sobolev Institute of Geology and Mineralogy, Siberian Branch of the Russian Academy of Sciences, \\ Novosibirsk 630090, Russia; taa@igm.nsc.ru (T.A.A.); avg@igm.nsc.ru (A.V.G.); \\ korsakov@igm.nsc.ru (A.V.K.) \\ 2 Department of Lithospheric Research, University of Vienna, Althanstraße 14/UZA2, Vienna 1090, Austria; \\ taisia.alifirova@univie.ac.at \\ * Correspondence: m.rezvukhin@igm.nsc.ru or m.rezvukhin@gmail.com
}

Received: 1 February 2020; Accepted: 10 March 2020; Published: 14 March 2020

check for updates

\begin{abstract}
More than forty mineral species of epigenetic origin have been identified in an orthopyroxenite from the Udachnaya-East kimberlite pipe, Daldyn kimberlite field, Siberian platform. Epigenetic phases occur as: (1) Mineral inclusions in the rock-forming enstatite, (2) daughter minerals within large (up to $2 \mathrm{~mm}$ ) crystallized melt inclusions (CMI) in the rock-forming enstatite, and (3) individual grains and intergrowths in the intergranular space of the xenolith. The studied minerals include silicates (olivine, clinopyroxene, phlogopite, tetraferriphlogopite, amphibole-supergroup minerals, serpentine-group minerals, talc), oxides (several generations of ilmenite and spinel, rutile, perovskite, rare titanates of the crichtonite, magnetoplumbite and hollandite groups), carbonates (calcite, dolomite), sulfides (pentlandite, djerfisherite, pyrrhotite), sulfate (barite), phosphates (apatite and phosphate with a suggested crystal-chemical formula $\mathrm{Na}_{2} \mathrm{BaMg}\left[\mathrm{PO}_{4}\right]_{2}$ ), oxyhydroxide (goethite), and hydroxyhalides (kuliginite, iowaite). The examined epigenetic minerals are interpreted to have crystallized at different time spans after the formation of the host rock. The genesis of minerals is ascribed to a series of processes metasomatically superimposed onto the orthopyroxenite, i.e., deep-seated mantle metasomatism, infiltration of a kimberlite-related melt and late post-emplacement hydrothermal alterations. The reaction of orthopyroxene with the kimberlite-related melt has led to orthopyroxene dissolution and formation of the CMI, the latter being surrounded by complex reaction zones and containing zoned olivine grains with extremely high-Mg\# (up to 99) cores. This report highlights the utility of minerals present in minor volume proportions in deciphering the evolution and modification of mantle fragments sampled by kimberlitic and other deep-sourced magmas. The obtained results further imply that the whole-rock geochemical analyses of mantle-derived samples should be treated with care due to possible drastic contaminations from "hiding" minor phases of epigenetic origin.
\end{abstract}

Keywords: epigenetic minerals; melt inclusions; xenolith; orthopyroxenite; kimberlite; multistage metasomatism; orthopyroxene dissolution; Udachnaya pipe; Siberian craton

\section{Introduction}

Epigenetic minerals are an important source of information on the nature of processes that modify primary mineral assemblages. Commonly represented in samples only in small volume proportions, epigenetic minerals do not affect the host rock classification, but in some cases may control the budget of rare and incompatible elements of the bulk mineral association [1-5]. In this regard, epigenetic minerals 
are similar to accessory ones; we distinguish between these based on a genetic context, i.e., "accessory" minerals are those formed from the same magma as the host rock, whereas "epigenetic" minerals crystallize at a later time during superimposed processes. The relevance of studying epigenetic and accessory minerals is defined by the possibility to obtain valuable data on the nature, migration and differentiation of fluids/melts in the Earth's interior encoded within these minor rock constituents.

A significant number of comprehensive publications is devoted to a geological setting and kimberlites of the Udachnaya mine (Daldyn field, Yakutian diamondiferous province, Siberian platform) consisting of two adjacent bodies, the West and the East (e.g., [6-13]). The Udachnaya-East kimberlite pipe is not only the leader of diamond production with a high diamond ore grade, but also a unique source of data on deep-seated mineral assemblages that occur as xenoliths and xenocrysts in a mantle-derived cargo of this natural well. Since the discovery of the Udachnaya kimberlite in 1955, increased attention has been paid to its deep-sourced xenogenic material. However, most of the works have dealt with pristine mineral associations, whereas superimposed mineralization and corresponding processes have been studied comparatively less intensively. In many samples brought to the surface by mantle-derived magmas epigenetic minerals occur as inclusions in rock-forming minerals and grains in intergranular space, which may significantly affect modal sample compositions, alter the incompatible element budget of the rock, and hamper the interpretation of its origin. For these reasons, epigenetic minerals are often considered as undesirable and are disregarded from detailed consideration in studies that focus on primary mineralogical, petrographic and geochemical features of mantle xenoliths. In some instances, however, newly formed (epigenetic) phases serve as a powerful means to establish the rock evolution, offering insights into the nature and composition of liquids affecting mantle-derived material [14-24].

This paper provides a systematic mineralogical characterization of the epigenetic mineral species identified in a mantle-derived xenolith UV-13-233. Although macroscopically the sample appears as being rather fresh and unaltered, it does comprise a remarkable suite of superimposed minerals recognized mostly on a microscale by using optical and scanning electron microscopy. We show that a rich variety of epigenetic minerals in the xenolith is linked to its complex modification and results from a series of superimposed processes, which influenced the host rock both at mantle depths and crustal levels. Implications for the nature of these processes are also discussed.

\section{Materials and Methods}

The study of minerals was carried out at the Analytical Center for multi-elemental and isotope research, Siberian Branch of the Russian Academy of Sciences (Sobolev Institute of Geology and Mineralogy SB RAS, Novosibirsk, Russia). Several polished cross-sections $5 \mathrm{~cm} \times 7.5 \mathrm{~cm}$ in size were prepared from the xenolith. For the purpose of this work, most of the optical observations and analytical procedures were performed on a single polished section that turned out as being representative enough to cover the entire range of the reported textures and mineral compositions.

Scanning electron microscopic (SEM) study was conducted using a MIRA 3 LMU device (Tescan, Brno, Czech Republic) coupled with an INCA 450+ energy-dispersive spectroscopic (EDS) system equipped with a liquid nitrogen-free XMax-80 Silicon Drift Detector (Oxford Instruments, Abingdon, UK). The operating conditions were as follows: an accelerating voltage of $20 \mathrm{kV}$, a current of $1 \mathrm{nA}$, and counting times of 20-30 s. SmartMap option of the INCA software (Oxford Instruments, Abingdon, UK) was employed to acquire compositional maps of the representative parts of an oxide intergrowth. X-ray data were collected at $512 \times 512$ pixel resolution with a total number of frames 200-400.

A JXA-8100 and a JXA-8230 electron microprobe (EMP) instruments (JEOL Ltd., Akishima, Japan) were employed to acquire wavelength-dispersive spectroscopic (WDS) analyses. The analytical conditions were $20 \mathrm{kV}$ and a beam diameter of $\sim 2-3 \mu \mathrm{m}$. A probe current varied depending on the mineral analyzed, e.g., for olivine, perovskite and rare titanates a relatively high beam current of $100 \mathrm{nA}$ was used, whereas for other minerals we employed a lower beam current at the range of 20-50 nA. The counting times were generally $10 \mathrm{~s}$ for peak and 5-10 s for each side of the background 
in most runs, albeit for the analysis of minor elements in olivine ( $\mathrm{Mn}, \mathrm{Ca}, \mathrm{Ni}, \mathrm{Cr}, \mathrm{P})$ the peak and off peak counting times were $180 \mathrm{~s}$ each. Instrument calibrations were performed using natural minerals and synthetic compounds taken from the in-house collection of standards at the Analytical Center for multi-elemental and isotope research SB RAS. For monitoring of stability and instrumental drift, we used a set of internal standards (mainly natural minerals, but also Ba- and Sr-doped synthetic glasses) from the same collection. Detection limits varied generally from 0.01 to $0.04 \mathrm{wt} \%$; limits of detection for minor components in olivine were 10-27 ppm. The processing of raw data was performed automatically by the ZAF correction routine. More detailed information concerning currently applied EMP procedures at IGM SB RAS has been reported elsewhere [25].

The Raman spectra of minerals were taken with a LabRam HR $800 \mathrm{~mm}$ spectrometer (Horiba Jobin Yvon, Kyoto, Japan) coupled with a Nd:YAG $532 \mathrm{~nm}$ excitation wavelength laser and an Olympus BX41 microscope. The approximate diameter of a laser beam was 1-2 $\mu \mathrm{m}$; laser power varied at a range of 4-40 $\mathrm{mW}$ to minimize destruction of the sample area. The Raman spectra were recorded at room temperature in the backscattering geometry with an Olympus MPlan 100× objective lens $(0.37 \mathrm{~mm}$ working distance, 0.9 numerical aperture). A Peltier-cooled charge coupled device (CCD) detector was utilized for data collection. Accumulation time was 50-100 s. To extract peak positions the Raman spectra were corrected by subtracting a baseline, and then a least-squares curve fitting of combined Gaussian functions was applied. Calculation precision was about $\pm 0.2 \mathrm{~cm}^{-1}$. The spectral resolution for the recorded Stokes-side Raman spectra was set to $\sim 2 \mathrm{~cm}^{-1}$ achieved by usage of 1800 grooves/mm gratings and $200 \mu \mathrm{m}$ slits. The system was calibrated using the $520.7 \mathrm{~cm}^{-1}$ Raman band of a silicon wafer before and after each analytical session. The Raman spectra of minerals were compared with the relevant ones from the open access RRUFF database [26] and published data.

Mineral abbreviations used in this report are as follows: Amp-amphibole; Ap-apatite; Atg-antigorite; Brt-barite; Cal-calcite; CGM-crichtonite-group mineral(s); Chr-chromite; Cpx-clinopyroxene (diopside); Dj-djerfisherite; Dol-dolomite; Gk-geikielite; Grt-garnet (pyrope); Gth-goethite; HGM-hollandite-group minerals; Ilm-ilmenite; Iow-iowaite; $\mathrm{K}-\mathrm{Fe}-\mathrm{Kph}$ - potassic ferri-katophorite, K-Fe-Trm—potassic ferri-taramite; Klg-kuliginite; K-MgAvs-potassic magnesio-arfvedsonite; K-Rct-potassic richterite; Mg-Chr-magnesio-chromite; Mg-Hst—magnesio-hastingsite; MGM-magnetoplumbite-group minerals; Mgt-magnetite; Mgt-Usp-Chr-magnetite-ulvöspinel-chromite solid solution; Ol-olivine (forsterite); Opx-orthopyroxene (enstatite); Phl—phlogopite; Pln—pleonaste; Pn—pentlandite; Po-pyrrhotite; Prd-priderite; Prv-perovskite; Rct-richterite, Rlg-redledgeite; Rt-rutile; Spl—spinel; Srp-serpentine; Tphl—-tetraferriphlogopite; YIHA-yimengite-hawthorneite series.

\section{Results}

\subsection{Sample Petrography}

Xenolith UV-13-233 was picked in the Udachnaya-East open-pit mine from a volcanoclastic partially serpentinized kimberlite unit at depths of 620-640 m. The sample shows a complex structure and consists of orthopyroxenite, intermediate garnet-orthopyroxene assemblage, and garnet clinopyroxenite. A considerable diversity of epigenetic minerals was established in the orthopyroxenitic part of the xenolith. Using a set of conventional geothermobarometers, the P-T equilibration parameters of the orthopyroxenite have been estimated to be as high as $\sim 800{ }^{\circ} \mathrm{C}$ and $\sim 35 \mathrm{kbar}$ ([27] and references therein).

The orthopyroxenite exhibits a coarse-grained texture and consists essentially of large (1-10 mm) subhedral enstatite crystals (Figure 1, Figure 2, and Figure 3a) with subsidiary clinopyroxene (sodic Cr-diopside), vein-like ("necklace") garnet (Cr-rich pyrope), and Cr-spinel (magnesio-chromite) occurring interstitial to enstatite. The electron microprobe data on the compositions of the rock-forming minerals have been reported elsewhere [27]. Enstatite grains are densely populated by numerous preferentially oriented lamellae of diopside and fine platelets $(0.1-5 \mu \mathrm{m}$ in thickness) of 
magnesio-chromite (Figure 1, Figure 2, and Figure 3a), with their compositions being identical to those of intergranular diopside and magnesio-chromite grains. The spectacular feature of the orthopyroxenite is that the enstatite grains also host another type of diopside and Cr-spinel inclusions, which may be discordant with the preferred orientation, have irregular shapes, and are generally much bigger than the fine oriented lamellae (up to $0.5 \mathrm{~mm}$ in length and up to $100 \mu \mathrm{m}$ thick; Figure 1c,d and Figure 2d-f). These anhedral inclusions are frequently associated within enstatite host with rutile, Mg-Cr-ilmenite, pentlandite, and rare chromium titanates of the magnetoplumbite and crichtonite groups.
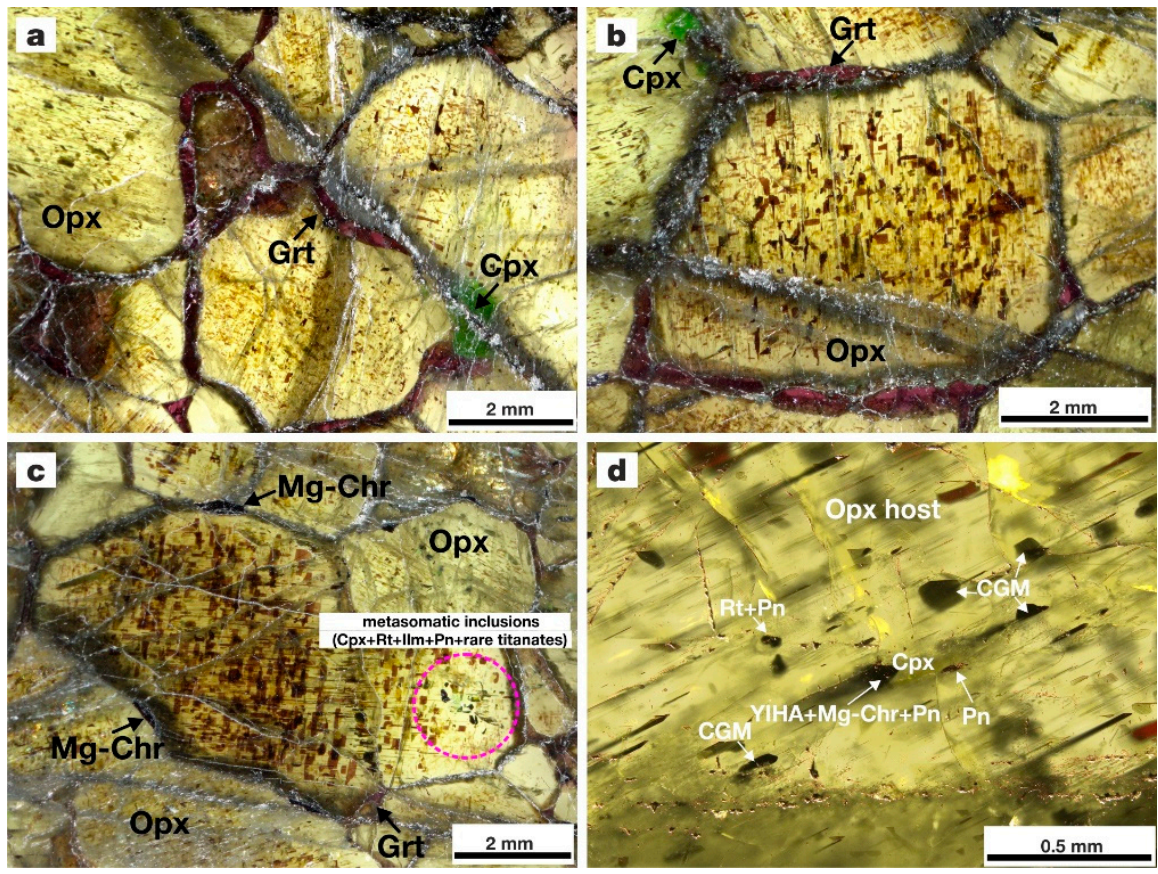

Figure 1. (a-d) Transmitted-light microphotographs showing typical textures of the orthopyroxenite. Enstatite grains enclose numerous oriented diopside lamellae (colorless; see also Figure 2) and magnesio-chromite platelets (brown). Diopside and magnesio-chromite are also found together with vein-like pyrope in between the enstatite grains. Note the superimposed metasomatic mineralization (diopside + rutile $+\mathrm{Mg}$-Cr-ilmenite + pentlandite + yimengite-hawthorneite series + crichtonite-group minerals) illustrated in images (c,d). (c) and (d) show different areas within the sample. Mineral abbreviations are those described in the Section "Materials and Methods" and Table 1.

Large (up to $2 \mathrm{~mm}$ ) globular and elongated crystallized melt inclusions (CMI) were recognized in the enstatite crystals located close to the sample margin (Figure 3). These are composed of a series of minerals similar to the host kimberlite groundmass. The volumetrically major mineral constituents of the CMI are olivine, serpentine, phlogopite, and tetraferriphlogopite; calcite, apatite, perovskite, and magnesio-chromite are presented in subordinate amounts. Other spinel-group minerals, sulfides (djerfisherite, pentlandite), barite, magnetite, and in a single case dolomite form small $(<15 \mu \mathrm{m})$ anhedral grains irregularly scattered in a volume of the inclusions. Olivine appears as euhedral prismatic crystals and aggregates of small $(<5 \mu \mathrm{m})$ rounded grains, with their proportion in the CMI varying in a broad range from $\sim 10$ to $\sim 90 \mathrm{vol} \%$. The interior of the CMI is often dominated by cryptocrystalline uniform serpentine pools (Figure 3). Within the pools, calcite and apatite occur as well-developed crystals (Figure $3 \mathrm{c}, \mathrm{d}, \mathrm{g}$ ), less commonly calcite is found as finely crystalline aggregates (Figure 3e). An irregular clustering of the olivine crystals forms an encasement of the serpentine pools. The majority of the CMI are surrounded by reaction zones, which are evident on back-scattered electron (BSE) images as bright-colored fringes around the globules (Figures 3k and 4). The reaction zones consist of several finely crystalline mineral layers: the innermost layer is composed of "spongy" aggregate of fine olivine grains, immediately adjacent to the latter is a layer of phlogopite, further 
out is a layer of tetraferriphlogopite, occasionally finely intergrown with diopside, and the outermost jagged margin is composed of amphibole (K-richterite) (Figure 4).
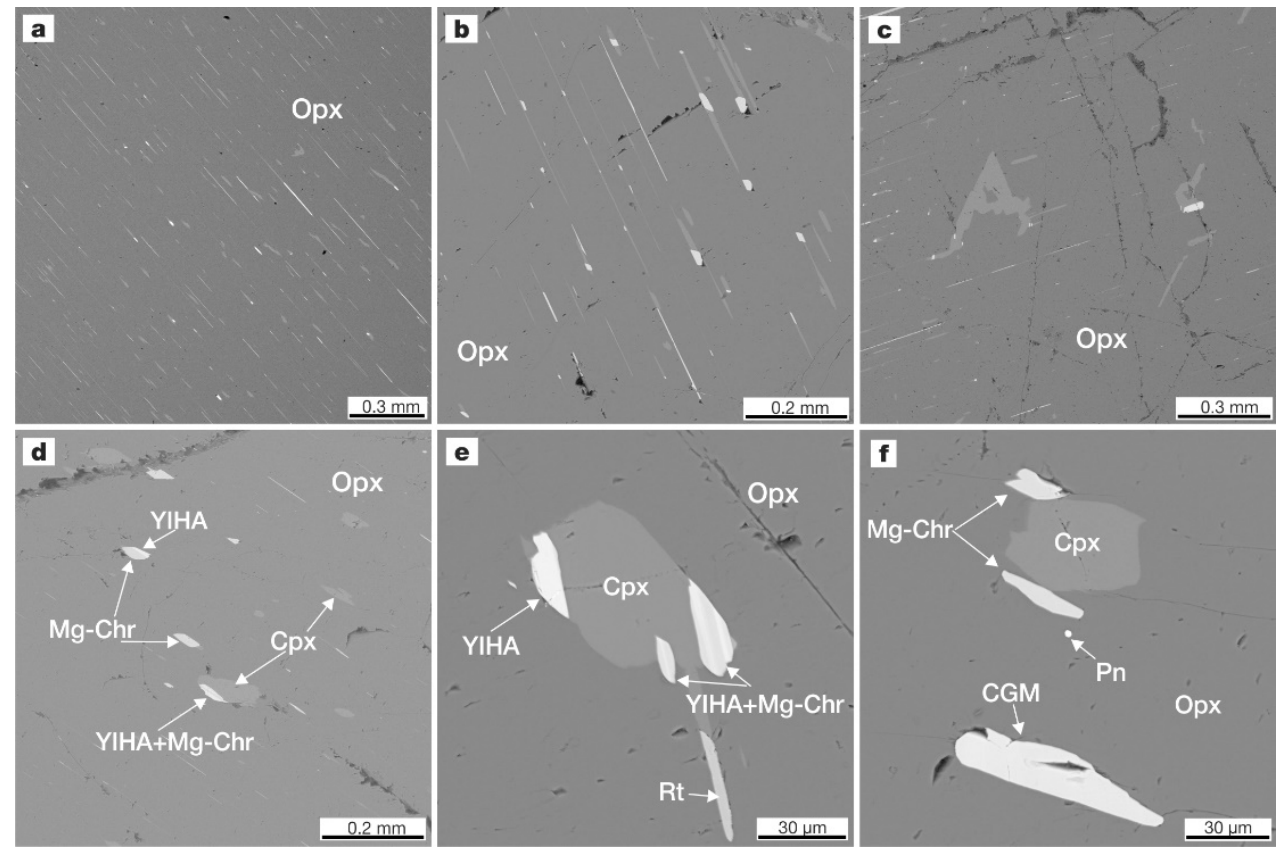

Figure 2. (a-c) Back-scattered electron (BSE) images showing the distribution of Cr-diopside (gray) and magnesio-chromite (light gray) inclusions in enstatite; (d-f) BSE images showing titanates of the yimengite-hawthorneite series and crichtonite-group minerals associated with titaniferous magnesio-chromite, irregularly-shaped $\mathrm{Cr}$-diopside, rutile and pentlandite. Mineral abbreviations are those described in the Section "Materials and Methods" and Table 1.

The intergranular space of the orthopyroxenite is characterized by the presence of the entire spectrum of the studied minerals (Figure 5), with the exception of the magnetoplumbite-group minerals (YIHA series) that occur only as inclusions in enstatite. Most of the space between the enstatite grains is occupied by vein-like pyrope, which is intensively rimmed by a kelyphite-like assemblage dominated by phlogopite, chromite and Al-rich amphiboles (Figure 5b). Some of the pyrope "necklaces" are almost completely replaced by these aggregates. Al-poor amphiboles of K-richterite-like compositions replace earlier-formed pyroxenes, especially enstatite (Figure $5 \mathrm{e}, \mathrm{h}, \mathrm{j}, \mathrm{k}$ ). Irregularly shaped patches and veins of serpentine develop in fractures, cavities, and as rims on pre-existing silicate minerals. Small $(<30 \mu \mathrm{m})$ apatite, calcite, barite, and sulfide grains are distributed disorderly within the amphibole and serpentine matrix. Oxide minerals are often recognized as inhomogeneous composite intergrowths that sporadically occur in the intergranular space of the rock. These oxide clusters can be subdivided into two types based on their constituent minerals: the first one comprises mineral species reminiscent of the inclusions in enstatite, i.e., rutile, titaniferous $\mathrm{Mg}$-rich chromite, crichtonite-group minerals and in rare cases $\mathrm{Mg}-\mathrm{Cr}$-ilmenite (Figure 5a; see also Figure 5 in [27]), whereas the intergrowths of the second type consist of Mn-enriched ilmenite-group minerals, perovskite, rutile, chromite, magnetite-ulvöspinel-chromite, and redledgeite (Figure 6). Within the intergrowths of the second type, minor apatite, phlogopite, tetraferriphlogopite, serpentine and calcite are found together with the oxide minerals. Both types of oxide intergrowths show a pronounced inhomogeneity in terms of mineral proportions and chemistry of individual mineral areas. 
Table 1. An integrated paragenetic scheme showing all the examined minerals and their affiliation to a specific process during the rock evolution.

\begin{tabular}{|c|c|c|c|c|c|c|c|c|}
\hline \multirow{2}{*}{ Class } & \multirow{2}{*}{ Group } & \multirow{2}{*}{ Mineral } & \multirow{2}{*}{ Formula } & \multirow{2}{*}{ Abbreviation } & \multicolumn{2}{|r|}{ Stage 1} & Stage 2 & \multirow{2}{*}{$\begin{array}{c}\text { Stage } 3 \\
\begin{array}{c}\text { Hydrothermal } \\
\text { Fluid Infiltration }\end{array}\end{array}$} \\
\hline & & & & & Orthopyroxenite & $\begin{array}{c}\text { Mantle } \\
\text { Metasomatism }\end{array}$ & $\begin{array}{l}\text { Kimberlite Melt } \\
\text { Infiltration }\end{array}$ & \\
\hline \multirow{17}{*}{ Silicates } & & enstatite $\left(\mathrm{Opx} x^{*}\right)$ & $(\mathrm{Mg}, \mathrm{Fe})_{2} \mathrm{Si}_{2} \mathrm{O}_{6}$ & Opx & + & & & \\
\hline & & Cr-pyrope $\left(\mathrm{Grt}^{*}\right)$ & $(\mathrm{Mg}, \mathrm{Fe})_{3} \mathrm{Al}_{2}\left(\mathrm{SiO}_{4}\right)_{3}$ & Grt & + & & & \\
\hline & & diopside $\left(C p x^{*}\right)$ & $\mathrm{CaMgSi}_{2} \mathrm{O}_{6}$ & Cpx & + & & & \\
\hline & & diopside (Cpx1) & $\mathrm{CaMgSi}_{2} \mathrm{O}_{6}$ & Cpx & & + & & \\
\hline & & diopside (Cp $\times 2)$ & $\mathrm{CaMgSi}_{2} \mathrm{O}_{6}$ & Cpx & & & + & \\
\hline & & olivine & $(\mathrm{Mg}, \mathrm{Fe})_{2} \mathrm{SiO}_{4}$ & $\mathrm{Ol}$ & & & + & \\
\hline & & phlogopite & $\mathrm{KMg}_{3} \mathrm{AlSi}_{3} \mathrm{O}_{10}(\mathrm{~F}, \mathrm{OH})_{2}$ & Phl & & & + & \\
\hline & & tetraferriphlogopite (Tphl1) & $\mathrm{KMg}_{3} \mathrm{Fe}^{3+} \mathrm{Si}_{3} \mathrm{O}_{10}(\mathrm{~F}, \mathrm{OH})_{2}$ & Tphl & & & + & \\
\hline & & tetraferriphlogopite (Tphl2) & $\mathrm{KMg}_{3} \mathrm{Fe}^{3+} \mathrm{Si}_{3} \mathrm{O}_{10}(\mathrm{~F}, \mathrm{OH})_{2}$ & Tphl & & & + & \\
\hline & \multirow{6}{*}{$\begin{array}{c}\text { Amphibole-group } \\
\text { minerals }\end{array}$} & K-richterite & $\mathrm{K}(\mathrm{NaCa}) \mathrm{Mg}_{5} \mathrm{Si}_{8} \mathrm{O}_{22}(\mathrm{OH})_{2}$ & K-Rct & & & + & \\
\hline & & richterite & $\mathrm{Na}(\mathrm{NaCa}) \mathrm{Mg}_{5} \mathrm{Si}_{8} \mathrm{O}_{22}(\mathrm{OH})_{2}$ & Rct & & & + & \\
\hline & & K-ferri-kataphorite & $\mathrm{K}(\mathrm{NaCa})\left(\mathrm{Mg}_{4} \mathrm{Fe}^{3+}\right)\left(\mathrm{Si}_{7} \mathrm{Al}\right) \mathrm{O}_{22}(\mathrm{OH})_{2}$ & K-Fe-Kph & & & + & \\
\hline & & K-magnesio-arfvedsonite & $\mathrm{KNa}_{2}\left(\mathrm{Mg}_{4} \mathrm{Fe}^{3+}\right) \mathrm{Si}_{8} \mathrm{O}_{22}(\mathrm{OH})_{2}$ & K-Mg-Avs & & & + & \\
\hline & & magnesio-hastingsite & $\mathrm{NaCa}_{2}\left(\mathrm{Mg}_{4} \mathrm{Fe}^{3+}\right)\left(\mathrm{Si}_{6} \mathrm{Al}_{2}\right) \mathrm{O}_{22}(\mathrm{OH})_{2}$ & Mg-Hts & & & + & \\
\hline & & K-ferri-taramite & $\mathrm{K}(\mathrm{NaCa})\left(\mathrm{Mg}_{3} \mathrm{Fe}^{3+}{ }_{2}\right)\left(\mathrm{Si}_{6} \mathrm{Al}_{2}\right) \mathrm{O}_{22}(\mathrm{OH})_{2}$ & K-Fe-Trm & & & + & \\
\hline & \multirow{6}{*}{$\begin{array}{l}\text { ilmenite-group } \\
\text { minerals }\end{array}$} & serpentine & $(\mathrm{Mg}, \mathrm{Fe})_{6}\left[\mathrm{Si}_{4} \mathrm{O}_{10}\right](\mathrm{OH})_{8}$ & Srp & & & & + \\
\hline & & talc & $(\mathrm{Mg}, \mathrm{Fe})_{3} \mathrm{Si}_{4} \mathrm{O}_{10}(\mathrm{OH})_{2}$ & Talc & & & & + \\
\hline \multirow{14}{*}{ Oxides } & & $\begin{array}{l}\text { Cr-rich geikielite-ilmenite } \\
\text { (Ilm1) }\end{array}$ & $(\mathrm{Mg}, \mathrm{Fe}) \mathrm{TiO}_{3}$ & Gk-Ilm & & + & & \\
\hline & & ferroan geikielite (Ilm2) & $(\mathrm{Mg}, \mathrm{Fe}) \mathrm{TiO}_{3}$ & Gk & & & + & \\
\hline & & Fe-poor geikielite (Ilm2) & $\mathrm{MgTiO}_{3}$ & Gk & & & + & \\
\hline & & Mn-rich ilmenite (Ilm3) & $(\mathrm{Fe}, \mathrm{Mn}, \mathrm{Mg}) \mathrm{TiO}_{3}$ & Mn-Ilm & & & + & \\
\hline & \multirow{7}{*}{$\begin{array}{l}\text { spinel-group } \\
\text { minerals }\end{array}$} & magnesio-chromite $\left(\mathrm{Spl}^{*}\right)$ & $(\mathrm{Mg}, \mathrm{Fe})\left(\mathrm{Cr}, \mathrm{Al}, \mathrm{Ti}_{2} \mathrm{O}_{4}\right.$ & $\mathrm{Mg}-\mathrm{Chr}$ & + & & & \\
\hline & & magnesio-chromite (Spl1) & $(\mathrm{Mg}, \mathrm{Fe})(\mathrm{Cr}, \mathrm{Al}, \mathrm{Ti})_{2} \mathrm{O}_{4}$ & Mg-Chr & & + & & \\
\hline & & magnesio-chromite (Spl2) & $(\mathrm{Mg}, \mathrm{Fe})(\mathrm{Cr}, \mathrm{Al}, \mathrm{Ti})_{2} \mathrm{O}_{4}$ & Mg-Chr & & & + & \\
\hline & & chromite (Spl3) & $(\mathrm{Fe}, \mathrm{Mg})(\mathrm{Cr}, \mathrm{Al}, \mathrm{Ti})_{2} \mathrm{O}_{4}$ & $\mathrm{Chr}$ & & & + & \\
\hline & & $\begin{array}{c}\mathrm{Fe}^{3+} \text {-Ti-Cr-rich spinels } \\
(\mathrm{Spl} 4)\end{array}$ & $(\mathrm{Fe}, \mathrm{Mg}, \mathrm{Mn})\left(\mathrm{Fe}^{3+}, \mathrm{Cr}, \mathrm{Ti}_{2}\right)_{2} \mathrm{O}_{4}$ & Mgt-Usp-Chr & & & + & \\
\hline & & spinel (pleonaste; Sp15) & $(\mathrm{Mg}, \mathrm{Fe}) \mathrm{Al}_{2} \mathrm{O}_{4}$ & Spl & & & + & \\
\hline & & magnetite (Spl6) & $\mathrm{Fe}^{2+} \mathrm{Fe}^{3+}{ }_{2} \mathrm{O}_{4}$ & $\mathrm{Mgt}$ & & & & + \\
\hline & & rutile $(\mathrm{R} \mathrm{t} 1)$ & $\mathrm{TiO}_{2}$ & $\mathrm{Rt}$ & & + & & \\
\hline & & rutile (Rt2) & $\mathrm{TiO}_{2}$ & Rt & & & + & \\
\hline & & perovskite & $\mathrm{CaTiO}_{3}$ & Prv & & & + & \\
\hline
\end{tabular}


Table 1. Cont

\begin{tabular}{|c|c|c|c|c|c|c|c|c|}
\hline \multirow{2}{*}{ Class } & \multirow{2}{*}{ Group } & \multirow{2}{*}{ Mineral } & \multirow{2}{*}{ Formula } & \multirow{2}{*}{ Abbreviation } & \multicolumn{2}{|r|}{ Stage 1} & \multirow{2}{*}{$\begin{array}{c}\text { Stage } 2 \\
\begin{array}{c}\text { Kimberlite Melt } \\
\text { Infiltration }\end{array}\end{array}$} & \multirow{2}{*}{$\begin{array}{c}\text { Stage } 3 \\
\text { Hydrothermal } \\
\text { Fluid Infiltration }\end{array}$} \\
\hline & & & & & Orthopyroxenite & $\begin{array}{c}\text { Mantle } \\
\text { Metasomatism }\end{array}$ & & \\
\hline \multirow{7}{*}{ Oxides } & \multirow{3}{*}{ CGM } & $\begin{array}{l}\text { K-Fe crichtonite-group } \\
\text { mineral }\end{array}$ & $(\mathrm{K}, \mathrm{Ba})(\mathrm{Fe}, \mathrm{Zr})\left(\mathrm{Ti}, \mathrm{Cr}, \mathrm{Fe}^{3+}, \mathrm{Al}\right)_{18}(\mathrm{Mg}, \mathrm{Fe})_{2} \mathrm{O}_{38}$ & CGM & & + & & \\
\hline & & $\begin{array}{l}\text { Ba-Fe crichtonite-group } \\
\text { mineral }\end{array}$ & $(\mathrm{Ba}, \mathrm{K})(\mathrm{Fe}, \mathrm{Zr})\left(\mathrm{Ti}, \mathrm{Cr}, \mathrm{Fe}^{3+}, \mathrm{Al}\right)_{18}(\mathrm{Mg}, \mathrm{Fe})_{2} \mathrm{O}_{38}$ & CGM & & + & & \\
\hline & & other CGM & $\mathrm{ABC}_{18} \mathrm{~T}_{2} \mathrm{O}_{38}$ & CGM & & + & & \\
\hline & \multirow{2}{*}{ MGM } & yimengite $(\mathrm{K})$ & $(\mathrm{K}, \mathrm{Ba})(\mathrm{Ti}, \mathrm{Cr}, \mathrm{Fe}, \mathrm{Al})_{12} \mathrm{O}_{19}$ & YIHA & & + & & \\
\hline & & hawthorneite (Ba) & $(\mathrm{Ba}, \mathrm{K})(\mathrm{Ti}, \mathrm{Cr}, \mathrm{Fe}, \mathrm{Al})_{12} \mathrm{O}_{19}$ & YIHA & & + & & \\
\hline & \multirow{2}{*}{ HGM } & priderite & $\mathrm{KFe}^{3+} \mathrm{Ti}_{7} \mathrm{O}_{16}$ & Prd & & & + & \\
\hline & & redledgeite & $\mathrm{BaCr}_{2} \mathrm{Ti}_{6} \mathrm{O}_{16}$ & $\operatorname{Rlg}$ & & & + & \\
\hline \multirow{3}{*}{ Carbonates } & & calcite (Cal1) & $\mathrm{CaCO}_{3}$ & Cal & & & + & \\
\hline & & calcite (Cal2) & $\mathrm{CaCO}_{3}$ & Cal & & & & + \\
\hline & & dolomite & $\mathrm{CaMg}\left(\mathrm{CO}_{3}\right)_{2}$ & Dol & & & & + \\
\hline \multirow{4}{*}{ Sulfides } & & pentlandite (Pn1) & $(\mathrm{Fe}, \mathrm{Ni})_{9} \mathrm{~S}_{8}$ & $\mathrm{Pn}$ & & + & & \\
\hline & & pentlandite (Pn2) & $(\mathrm{Fe}, \mathrm{Ni}, \mathrm{Co})_{9} \mathrm{~S}_{8}$ & Pn & & & + & \\
\hline & & djerfisherite & $\mathrm{K}_{6}(\mathrm{Fe}, \mathrm{Ni}, \mathrm{Cu})_{25} \mathrm{~S}_{26} \mathrm{Cl}$ & $\mathrm{Dj}$ & & & + & \\
\hline & & pyrrhotite & $\mathrm{Fe}(1-\mathrm{x}) \mathrm{S}$ & Po & & & + & \\
\hline Sulfate & & barite & $\mathrm{BaSO}_{4}$ & Brt & & & + & + \\
\hline \multirow{2}{*}{ Phosphates } & & apatite & $\mathrm{Ca}_{10}\left[\mathrm{PO}_{4}\right]_{6}(\mathrm{~F}, \mathrm{Cl}, \mathrm{OH})_{2}$ & Ap & & & + & \\
\hline & & Ba-Na-Mg phosphate & $\mathrm{Na}_{2} \mathrm{BaMg}\left(\mathrm{PO}_{4}\right)_{2}$ & & & & + & \\
\hline \multirow{3}{*}{$\begin{array}{l}\text { Oxyhydroxides } \\
\text { and } \\
\text { hydroxyhalides }\end{array}$} & & goethite & $\mathrm{Fe}^{3+} \mathrm{O}(\mathrm{OH})$ & Gth & & & & + \\
\hline & & kuliginite & $\mathrm{Fe}_{3} \mathrm{Mg}(\mathrm{OH})_{6} \mathrm{Cl}_{2}$ & $\mathrm{Klg}$ & & & & + \\
\hline & & iowaite & $\mathrm{Mg}_{4} \mathrm{Fe}^{3+}(\mathrm{OH})_{8} \mathrm{OCl} \cdot 3\left(\mathrm{H}_{2} \mathrm{O}\right)$ & Iow & & & & + \\
\hline
\end{tabular}

Notes: Mineral abbreviations in parentheses in the column "Mineral" denote different mineral generations, either of a single mineral (e.g., Pn1, Pn2) or of mineral species within a group (e.g., Spl1, Spl2, etc.,). Asterix (e.g., Opx ${ }^{*}, \mathrm{Cpx}^{*}$ ) indicates minerals present in the orthopyroxenitic assemblage prior to the superimposed metasomatic processes. "+" denotes the affiliation of mineral to a particular process (paragenesis) specified in the first row of the Table. 


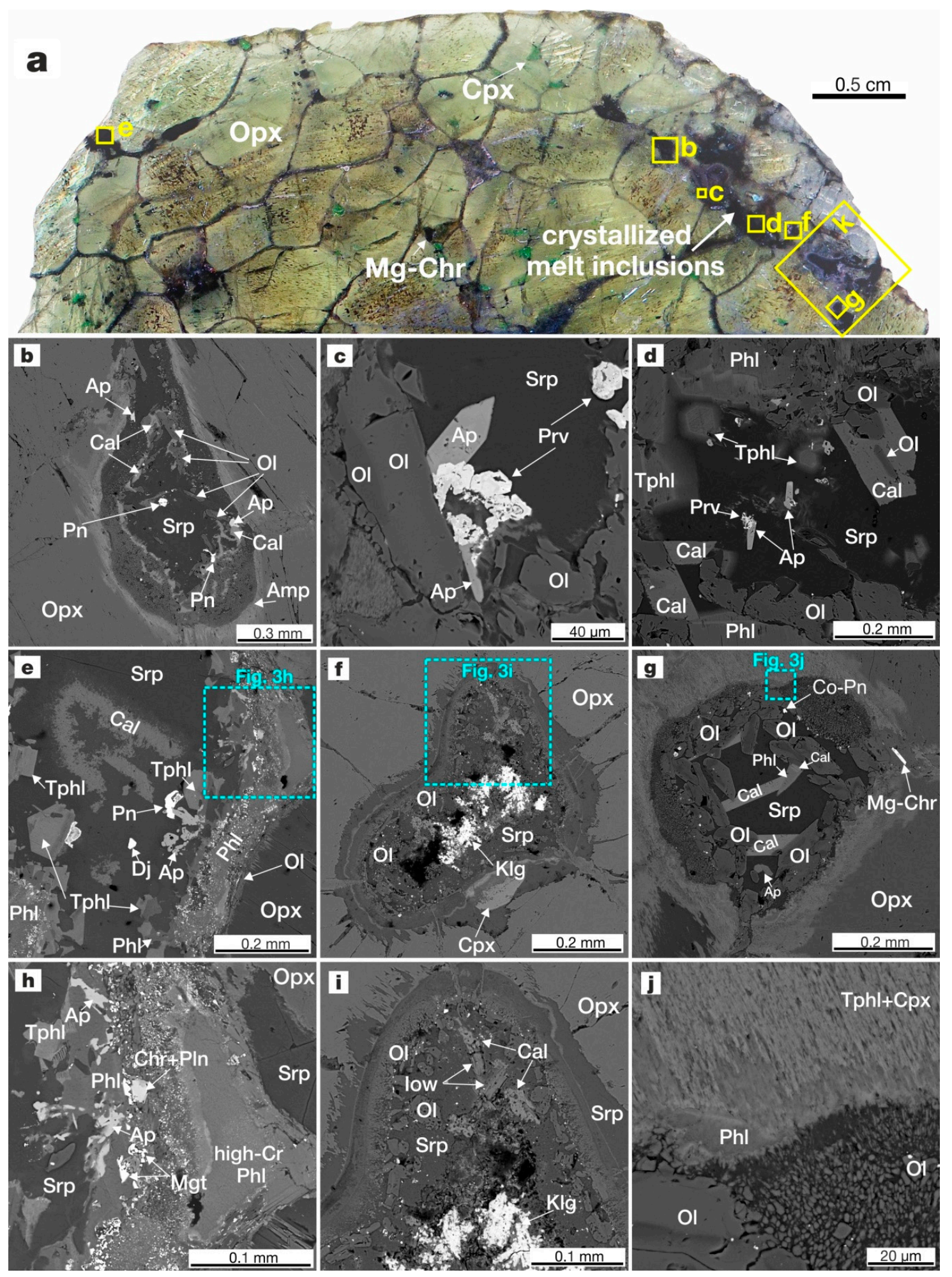

Figure 3. (a) Polished thin section made up of the orthopyroxenite with a marginal part containing crystallized melt inclusions; (b-j) BSE images depicting close-ups of the crystallized melt inclusions; (k) BSE image depicting a general view of the crystallized melt inclusions in orthopyroxene. Mineral abbreviations are those described in the Section "Materials and Methods" and Table 1. 


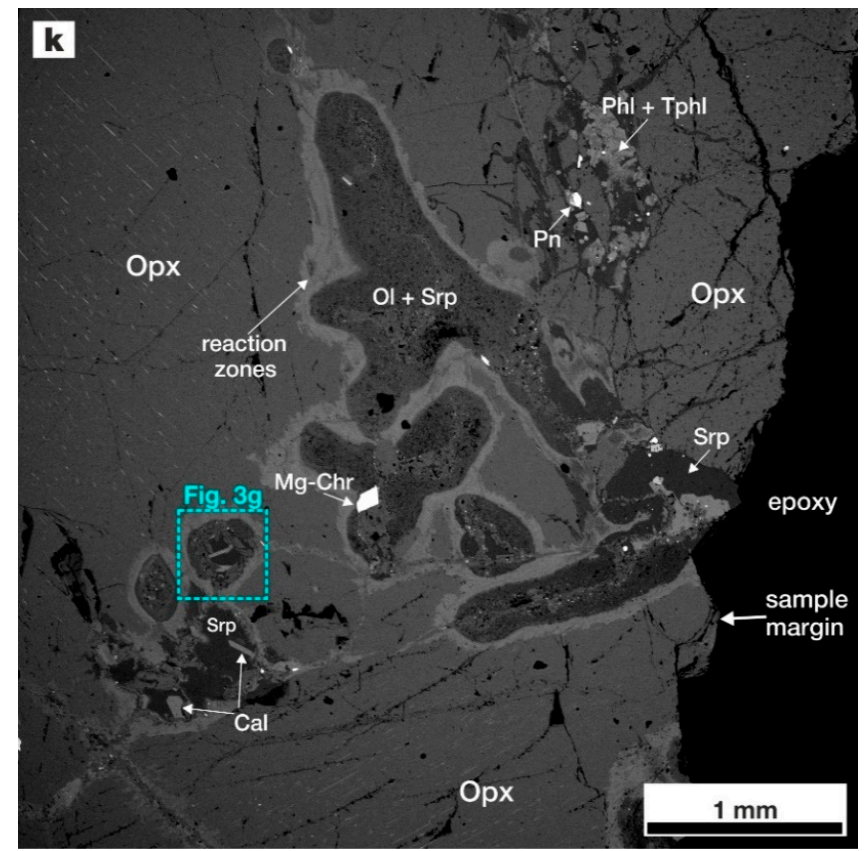

Figure 3. Cont.
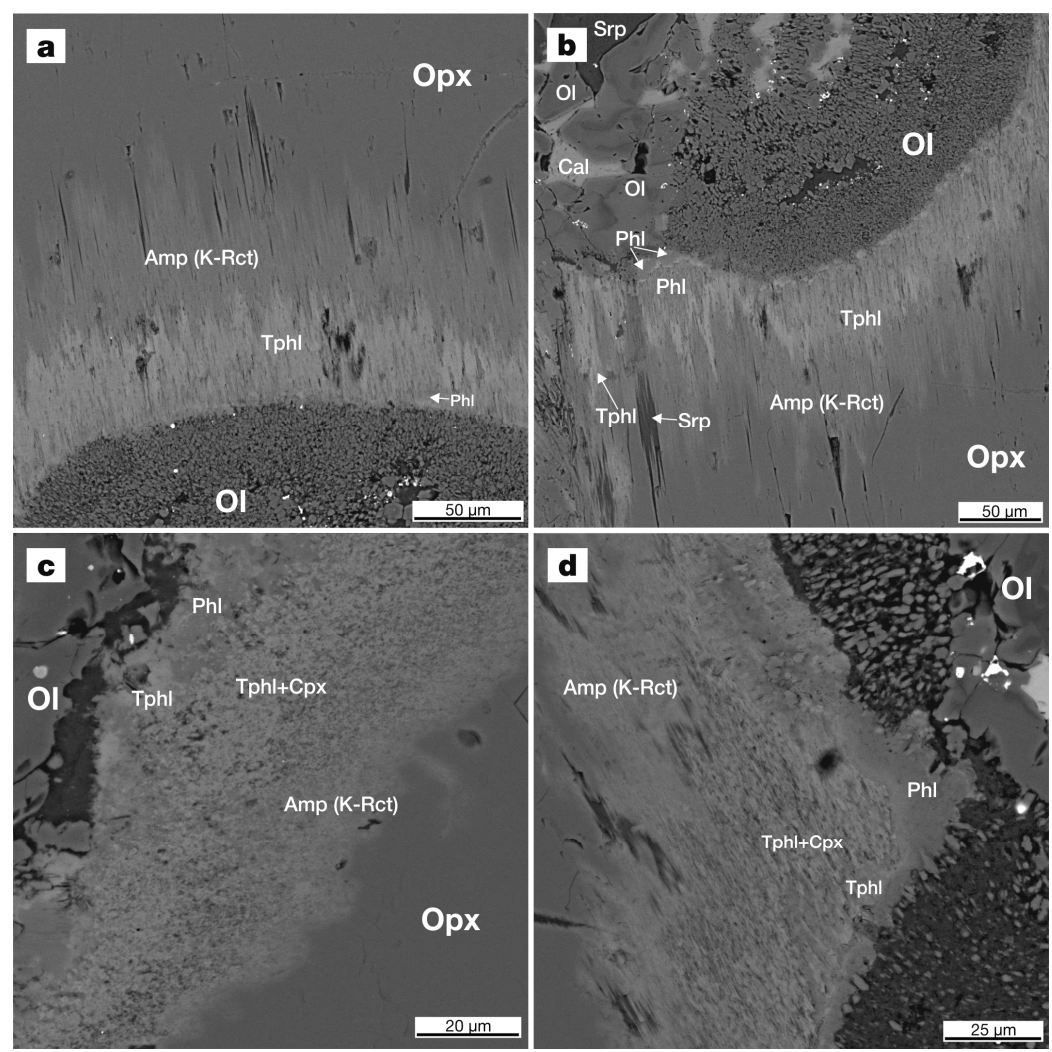

Figure 4. (a-d) BSE images showing the layered internal texture and mineral composition $(\mathrm{Ol} \rightarrow$ $\mathrm{Phl} \rightarrow \mathrm{Tphl} \pm \mathrm{Cpx} \rightarrow \mathrm{K}-\mathrm{Rct}$ ) of the reaction zones between the crystallized melt inclusions and host orthopyroxene. Mineral abbreviations are those described in the Section "Materials and Methods" and Table 1. 

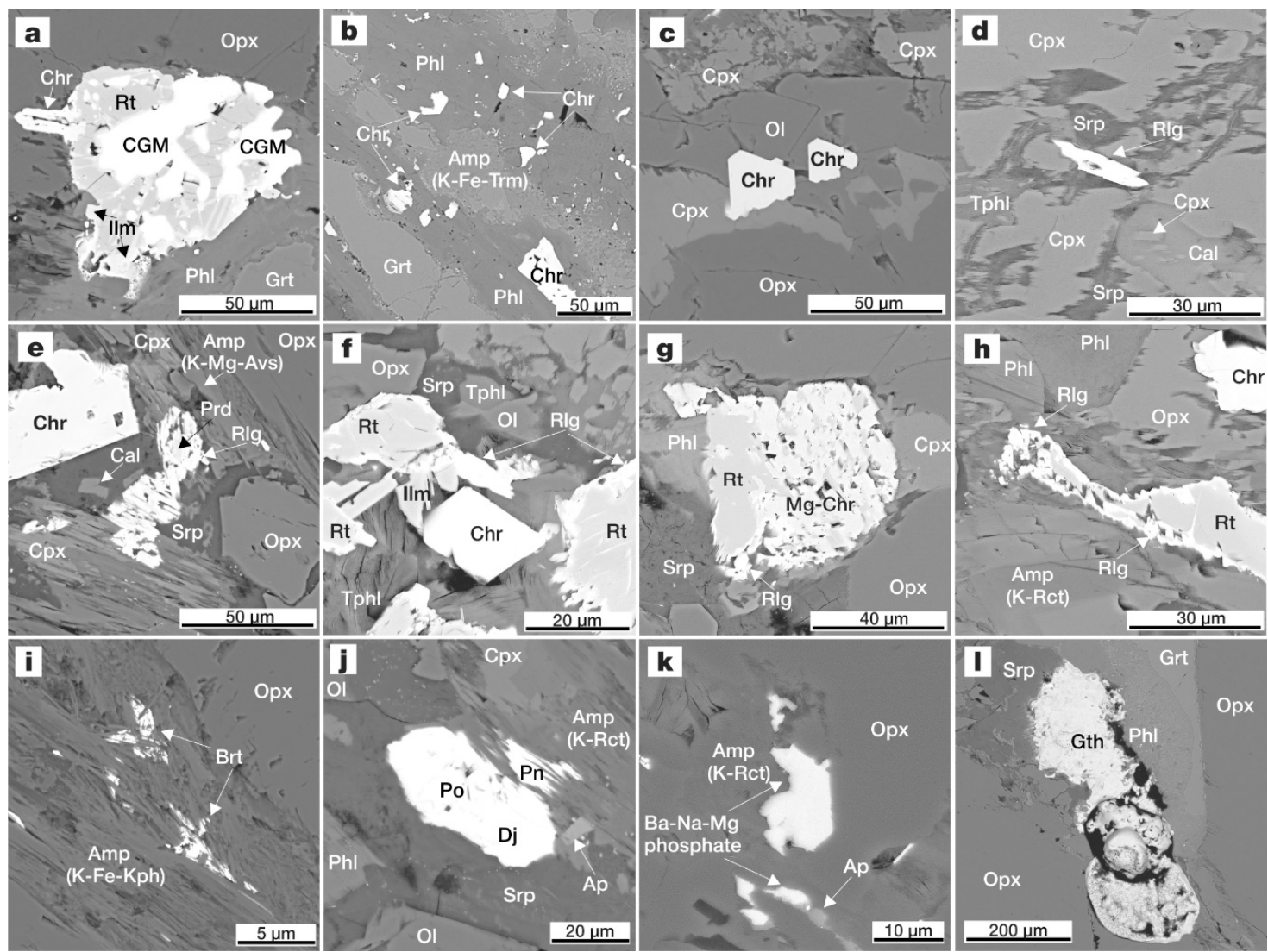

Figure 5. BSE images depicting minerals found in the intergranular space of the orthopyroxenite. (a) an inhomogeneous oxide intergrowth consisting of crichtonite-group minerals, rutile, chromite and ilmenite; (b) an aggregate composed of Al-rich potassic amphibole, chromite and phlogopite that replaces pre-existing garnet; (c) euhedral chromite crystals; $(\mathbf{d}-\mathbf{h})$ redledgeite occurrences, either as an individual crystal (d) or as thin rims on other oxide minerals (f-h); (i) barite specks associated with Al-poor potassic amphibole; (j) a polymineralic sulfide aggregate composed of pentlandite, pyrrhotite and djerfisherite; (k) an euhedral crystal of Ba-Na-Mg phosphate associated with apatite and K-richterite; (1) a reniform accumulation of goethite. Mineral abbreviations are those described in the Section "Materials and Methods" and Table 1.

The occurrences of minerals and their compositional peculiarities are considered at some length below. The representative chemical compositions are provided in Supplementary Tables S1-S7, while the Raman spectra of some species of interest are shown in Figure 7. 


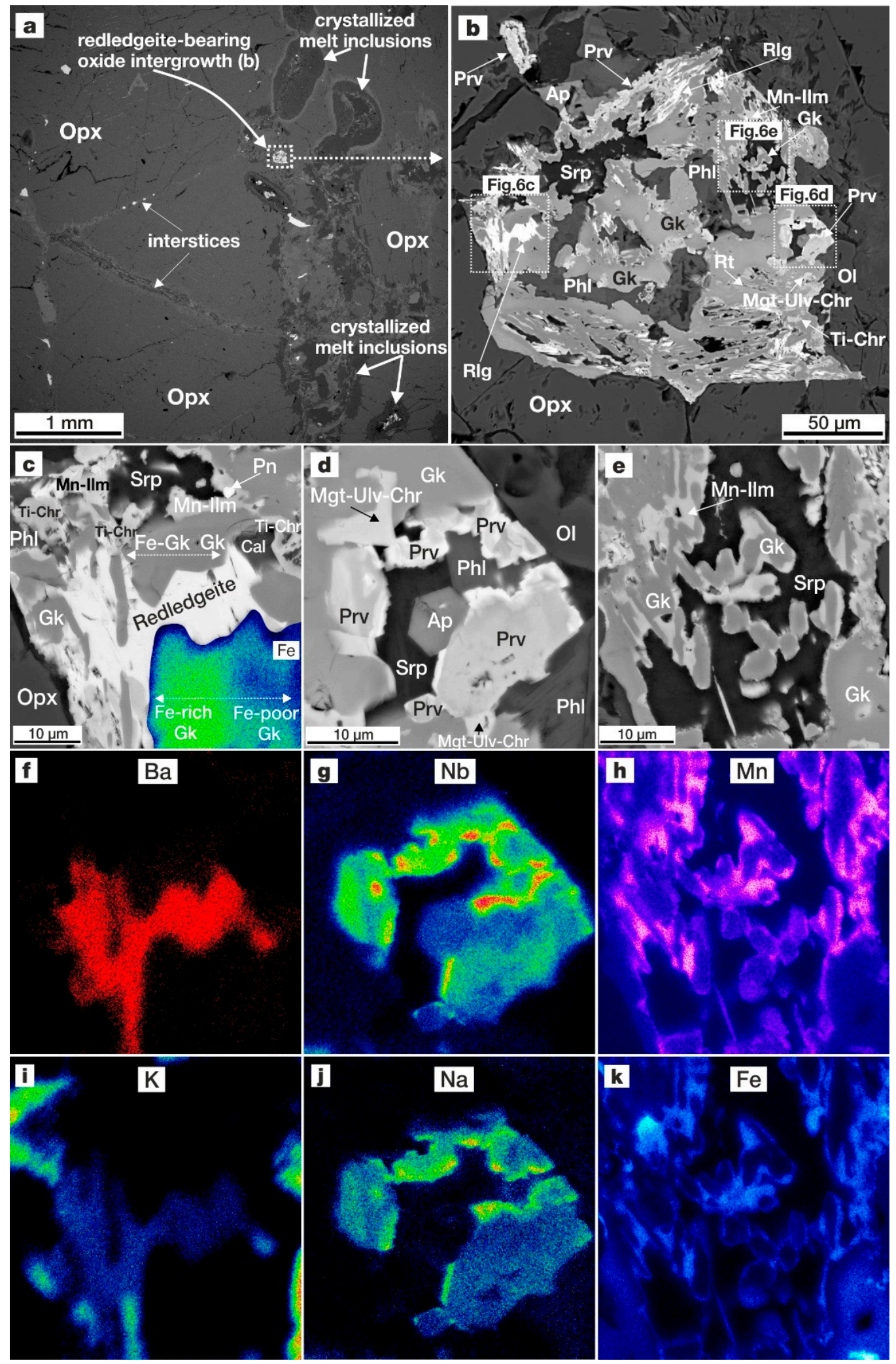

Figure 6. (a) BSE image showing an overview of the orthopyroxenite textures in a marginal area with the crystallized melt inclusions; (b-e) BSE images showing a characteristic inhomogeneous intergrowth, comprising kimberlitic (geikielite, perovskite, rutile, chromite, magnetite-ulvöspinel-chromite, apatite, phlogopite, olivine, Mn-rich ilmenite, redledgeite) and late-stage hydrothermal (serpentine) minerals; (f-k) X-ray elemental maps of the areas shown in (c-e), respectively. Mineral abbreviations are those described in the section "Materials and Methods" and Table 1. 

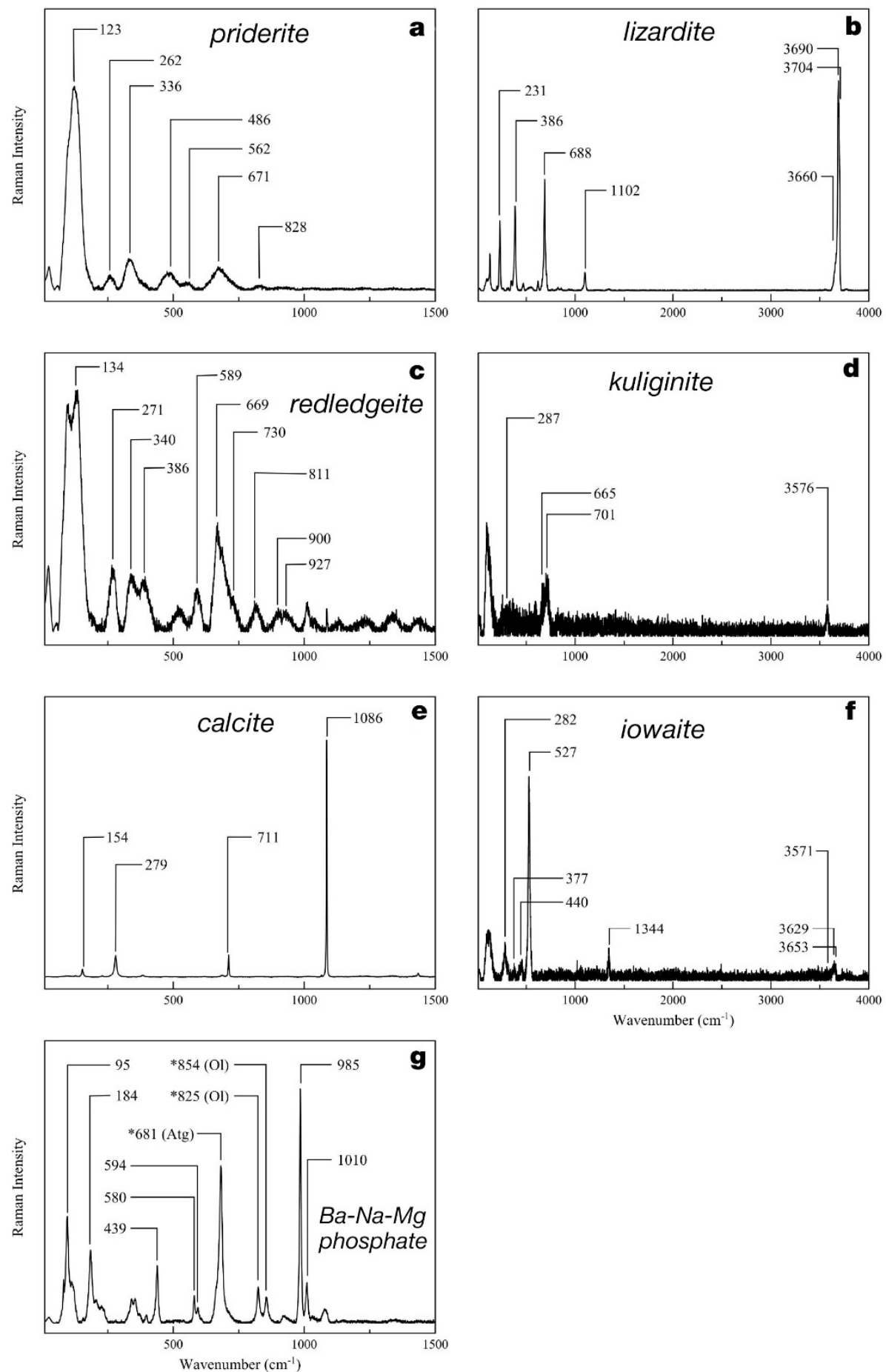

Figure 7. (a-g) Raman spectra of the examined minerals. (g) shows the Raman spectra of Ba-Na-Mg phosphate with contributions from associated olivine (Ol) and antigorite (Atg).

\subsection{Occurrences and Compositions of Minerals}

\subsubsection{Silicates}

Olivine, $(\mathrm{Mg}, \mathrm{Fe})_{2} \mathrm{SiO}_{4}$, is widely distributed in the $\mathrm{CMI}$ as an essential daughter mineral. Olivine forms idiomorphic crystals up to $100 \mu \mathrm{m}$ in size, often framing serpentine pools, the latter filling the central part of the melt droplets (Figure 3). The olivine crystals are often zoned, with the cores being highly magnesian (Fo 95.6-98.9) and the rims showing enrichment in Fe (Fo 92.2-94.4). The core-rim 
boundary distinguished by differences in Fo between the two zones within the olivine crystals is irregularly shaped and only in a limited number of grains both zones were large enough to acquire their reliable EMP analyses. Besides $\mathrm{FeO}$, the rims exhibit a pronounced increase in $\mathrm{MnO}(0.23-0.35 \mathrm{wt} \%)$ and $\mathrm{Cr}_{2} \mathrm{O}_{3}(0.02-0.16 \mathrm{wt} \%)$ compared to the core parts $(0.08-0.24 \mathrm{wt} \%$ and $<0.05 \mathrm{wt} \%$, respectively). There is no regular pattern in the distribution of $\mathrm{Ni}$ and $\mathrm{Ca}$ between the cores and rims of the olivine crystals; the overall abundance of $\mathrm{NiO}$ is relatively low (mostly below $0.20 \mathrm{wt} \%$, mean 0.10 , with a single exception showing $0.37 \mathrm{wt} \%$ ), whereas $\mathrm{CaO}$ varies widely in the core parts from 0.01 to $0.36 \mathrm{wt} \%$ and either increases or decreases rimward to a narrower range $(0.05-0.10 \mathrm{wt} \%)$. In the CMI olivine shows a "spongy" texture as well, comprising an aggregate of small $(<5 \mu \mathrm{m})$ crystals embedded in a matrix made up of finely grained serpentine (Figures $3 \mathbf{j}$ and 4 ). The size of the olivine crystals decreases from the interior of the CMI outward, so that the "spongy" olivine is recognized in the outer parts of the droplets. The compositions of the "spongy" olivine and homogeneous olivine crystals in terms of Fo (90.3-94.4) and minor elements generally correspond to those of rim parts of the zoned grains, although show greater variations. In the interstitial space of the rock olivine is associated with the same minerals as in the CMI; here its Fo is further decreased toward lower values (Fo 89.1-91.4). Co-variation diagrams showing the composition of olivine are presented in Figure 8.

Diopside, $\mathrm{CaMgSi}_{2} \mathrm{O}_{6}$, is present as relatively large (up to $0.5 \mathrm{~mm}$ ) discrete grains interstitial to enstatite and fine lamellae within the enstatite $\left(\boldsymbol{C} p \boldsymbol{x}^{*}\right.$; Figure 1, Figure 2, Figure 3a). These are sodic $\mathrm{Cr}$-Al-diopsides $\left(\mathrm{Na}_{2} \mathrm{O}=2.6-2.7 ; \mathrm{Cr}_{2} \mathrm{O}_{3}=2.2-2.4 ; \mathrm{Al}_{2} \mathrm{O}_{3}=2.8-3.0 \mathrm{wt} \%\right)$ that are interpreted to represent the host rock (orthopyroxenitic) assemblage. Cpx1 forms irregularly shaped inclusions associated with titanate minerals within enstatite grains (Figures $1 \mathrm{~d}$ and $2 \mathrm{c}-\mathrm{f}$ ); these probably represent recrystallized and coalesced lamellae of $C p x^{*}$ showing increased $\mathrm{Na}_{2} \mathrm{O}(3.0 \mathrm{wt} \%)$. C $p x 2$ constitutes reaction zones between the CMI and host enstatite (Figure 4). Here $C p x 2$ is finely intergrown with tetraferriphlogopite and thus it is impossible to acquire its plausible EMP analysis without significant compositional contributions from the tetraferriphlogopite. However, based on available SEM EDS data, $C p x 2$ appears to be chemically distinct from $C p x^{*}$ and $C p x 1$ in terms of much lower amounts of $\mathrm{Na}, \mathrm{Cr}$, and $\mathrm{Al}\left(<0.6 \mathrm{wt} \%\right.$ of $\mathrm{Na}_{2} \mathrm{O}, \mathrm{Cr}_{2} \mathrm{O}_{3}$ and $\left.\mathrm{Al}_{2} \mathrm{O}_{3}\right)$, i.e., it is more pure diopside.

Trioctahedral ferromagnesian micas, phlogopite, $\mathrm{KMg}_{3} \mathrm{AlSi}_{3} \mathrm{O}_{10}(\mathrm{~F}, \mathrm{OH})_{2}$, and tetraferriphlogopite, $\mathrm{KMg}_{3} \mathrm{Fe}^{3+} \mathrm{Si}_{3} \mathrm{O}_{10}(\mathrm{~F}, \mathrm{OH})_{2}$, are among major components of the CMI (Figure 3). Inside the droplets, tetraferriphlogopite commonly develops well-shaped crystals displaying hexagonal, tabular, and square cross sections (Figure $3 \mathrm{~d}, \mathrm{e}$ ), whereas phlogopite occurs mostly as rounded irregular crystals and their aggregates (Figure 3d,e,h). The two micas often occur in juxtaposition, forming intergrowths and closely packed mosaics. Within the intergrowths, tetraferriphlogopite is located on the outer side, implying its later formation compared to the phlogopite. Both minerals compose the reaction zones between the CMI and host orthopyroxene, with phlogopite located closer to the inclusion interior (Figure 4). The compositions of phlogopite differ among melt droplets ( $\mathrm{w} t \%, \mathrm{Al}_{2} \mathrm{O}_{3}=10.1-17.1 ; \mathrm{TiO}_{2}=$ $0.25-2.44 ; \mathrm{FeO}_{\text {total }}=1.87-5.61 ; \mathrm{BaO}$ is up to $\left.1.10 ; \mathrm{F}=0.18-0.71\right) . \mathrm{Cr}_{2} \mathrm{O}_{3}$ in the phlogopite is generally up to $1.5 \mathrm{wt} \%$, but occasionally is exceptionally high up to $4.72 \mathrm{wt} \%$ (Figure $3 \mathrm{~h}$ ). Tetraferriphlogopite occurs in the $\mathrm{CMI}$ as two distinct varieties, both being $\mathrm{Al}_{2} \mathrm{O}_{3}$-deficient $(<0.6 \mathrm{wt} \%)$. The first one (Tphl1), is a typical tetraferriphlogopite containing 11.3-15.4 wt\% FeO total, 40.7-44.9 $\mathrm{SiO}_{2}$, and low $\mathrm{TiO}_{2}(<1 \mathrm{wt} \%)$, whereas the second species (Tphl2) contains only 5.32-7.31 wt\% FeOtotal, yet higher $\mathrm{SiO}_{2}(44.9-46.2 \mathrm{wt} \%)$ and $\mathrm{TiO}_{2}(2.09-2.44 \mathrm{wt} \%)$. BaO in the tetraferriphlogopites is below detection limits. At places, the tetraferriphlogopites are irregularly zoned from Tphl2 to Tphl1. All the examined micas occur in the intergranular space and show there essentially the same compositions as in the CMI, with the exception of $\mathrm{Na}_{2} \mathrm{O}$ that is low $(<0.30 \mathrm{wt} \%)$ in the CMI phlogopite and is substantially higher $(0.30-0.70 \mathrm{wt} \%)$ in the intergranular one.

The studied amphibole-supergroup minerals, $\mathrm{AB}_{2} \mathrm{C}_{5} \mathrm{~T}_{8} \mathrm{O}_{22} \mathrm{~W}_{2}$, are monoclinic and belong to the group

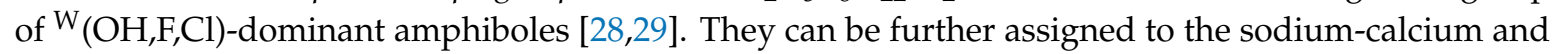
calcium subgroups based on the B-site occupancies [28,29], whereas the A site is dominated either by $\mathrm{K}$ or Na. Potassic richterite is a mineral that composes the outermost margin of the reaction zones between 
the $\mathrm{CMI}$ and host orthopyroxene (Figure 4). Here K-richterite contains low $\mathrm{Al}_{2} \mathrm{O}_{3}(0.84-1.32 \mathrm{wt} \%$ ) and $\mathrm{TiO}_{2}(0.77-1.00 \mathrm{wt} \%)$. Intergranular space hosts two types of the amphibole minerals, Al-poor and Al-rich. The first type comprises a suite of amphiboles generally similar in composition to the K-richterite occurring in the reaction zones, i.e., K-richterite (sensu stricto), richterite (with the prevalence of $\mathrm{Na}$ over $\mathrm{K}$ in the $\mathrm{A}$ site), their $\mathrm{TiO}_{2}$-enriched (2.75-5.91 $\mathrm{wt} \%$ ) varieties, also species classified as potassic ferri-katophorite and potassic magnesio-arfvedsonite. All these mineral species contain less than $1.0 \mathrm{wt} \%$ of $\mathrm{Al}_{2} \mathrm{O}_{3}$. As in the case of K-richterite occurring in the reaction zones, the identified suite of Al-poor amphiboles in the intergranular space appears to have been formed at the expense of orthopyroxene (Figure 5e,h-k). The second group is presented by Al-rich amphiboles containing 2.0-2.5 $\mathrm{Al}$ atoms per formula unit (apfu) in the $\mathrm{T}$ site, and $0.30-0.35 \mathrm{Al}$ apfu in the $\mathrm{C}$ site, which corresponds to $\sim 13-17 \mathrm{wt} \%$ of $\mathrm{Al}_{2} \mathrm{O}_{3}$. The two identified species of Al-rich amphibole are magnesio-hastingsite and potassic ferri-taramite; these are also rich in $\mathrm{Cr}_{2} \mathrm{O}_{3}(1.71-5.79 \mathrm{wt} \%)$. The Al-rich amphiboles are found closely associated with phlogopite in kelyphite-like assemblages replacing vein-like pyrope (Figure $5 b$ ).

Although macroscopically the xenolith appears as being virtually unaltered, serpentine, $\mathrm{Mg}_{6}\left[\mathrm{Si}_{4} \mathrm{O}_{10}\right](\mathrm{OH})_{8}$, and talc, $\mathrm{Mg}_{3} \mathrm{Si}_{4} \mathrm{O}_{10}(\mathrm{OH})_{2}$, find manifestations on the microscale. Micro-Raman study (Figure $7 \mathrm{~b}, \mathrm{~g}$ ) confirmed serpentine as being presented by predominant lizardite (in the CMI and intergranular space) and subsidiary antigorite (occurring only occasionally in the intergranular space). Lizardite forming extremely fine-grained pools in the CMI shows high Mg\# from 91.7 to 98.4, though the majority of analyses exceeds 95 (mean 96.2). Interstitial serpentine is defined by generally lower Mg\# values, which fall in a range of 86.4-94.6 (mean 90.8). Chlorine levels are $0.11-0.67 \mathrm{wt} \%$ in the CMI serpentine, whereas interstitial varieties contain much more $\mathrm{Cl}(0.19-1.78 \mathrm{wt} \%)$ on average. All the textural varieties are very pure serpentines characterized by low amounts of $\mathrm{Cr}_{2} \mathrm{O}_{3}, \mathrm{TiO}_{2}, \mathrm{Al}_{2} \mathrm{O}_{3}$, $\mathrm{CaO}$, and $\mathrm{Na}_{2} \mathrm{O} . \mathrm{SiO}_{2}$ concentration in the serpentines is about $41 \mathrm{wt} \%$. Fe-rich talc $(6.55 \mathrm{wt} \% \mathrm{FeO})$ was found at the contact between enstatite and diopside, definitely as a secondary mineral replacing the pyroxenes.

\subsubsection{Oxides}

Ilmenite-group minerals, $(\mathrm{Fe}, \mathrm{Mg}, \mathrm{Mn}) \mathrm{TiO}_{3}$, display a considerable range of occurrences and compositions within the rock. An ilmenite-geikielite (Ilm:Gk $=\sim 50: 50$ ) solid-solution enriched in $\mathrm{Cr}_{2} \mathrm{O}_{3}(3.93-5.08 \mathrm{wt} \%)$ is found as inclusions in enstatite and rarely in the intergranular space (Ilm1). Such compositions fall in a general range for upper mantle ilmenites found in metasomatized xenoliths [30]; MnO levels in these grains do not exceed $0.3 \mathrm{wt} \%$. By contrast, the intergranular space of the orthopyroxenite accommodates mostly ilmenite-group mineral varieties with the compositions showing enrichment in $\mathrm{Mg}$ and $\mathrm{Mn}$. These inhomogeneous ilmenite grains (Figure 6b-e) demonstrate a continuous range of compositions from ferroan geikielite to Fe-poor geikielite, with $\mathrm{MgO}$ and $\mathrm{MnO}$ gradually increasing from $\sim 15$ to $\sim 25 \mathrm{wt} \%$ and from $\sim 1.4$ to $\sim 4.7 \mathrm{wt} \%$, respectively. These geikielite compositions are collectively defined as IIm2. Ilmenite of the third generation (Ilm3) is present in a minor volume proportion and mantles $\mathrm{Ilm} 2$ (Figure 6e,h,k). Ilm3 is $\mathrm{FeTiO}_{3}$-dominant (ilmenite), yet contains the highest $\mathrm{MnO}$ (up to $17.2 \mathrm{wt} \%$, corresponding to $\sim 35 \mathrm{~mol} \%$ of the pyrophanite component), $\mathrm{Nb}_{2} \mathrm{O}_{5}$ (up to $1.45 \mathrm{wt} \%$ ), and $\mathrm{Ta}_{2} \mathrm{O}_{5}$ (up to $0.23 \mathrm{wt} \%$ ) among the studied ilmenites, whereas $\mathrm{MgO}$ drops to $\sim 6 \mathrm{wt} \%$. Chromium levels decrease from $\sim 4-5 \mathrm{wt} \% \mathrm{Cr}_{2} \mathrm{O}_{3}$ in $I l m 1$ and the most Fe-rich Ilm2 to $1.0-1.5 \mathrm{wt} \% \mathrm{Cr}_{2} \mathrm{O}_{3}$ in the most Mg-rich Ilm2 and Ilm3.

Similar to the ilmenite-group members, minerals of the spinel supergroup (spinel subgroup, $\mathrm{A}^{2+} \mathrm{B}^{3+}{ }_{2} \mathrm{O}_{4}$, [31]) show wide compositional variations owing to extensive substitution series occurring among various end-member spinel molecules, which implies several generations of formation. Large (up to $1 \mathrm{~mm}$ ) spinel grains interstitial to enstatite and numerous spinel lamellae within enstatite are presented by aluminous magnesio-chromite $\left(\mathrm{Spl}^{*}\right)$ with relatively low contents of $\mathrm{TiO}_{2}(<1.2 \mathrm{wt} \%)$. These are characterized by high $\mathrm{Cr} \#=100 \times \mathrm{Cr} /(\mathrm{Cr}+\mathrm{Al}) \geq 68$ and $\mathrm{Mg} \#=100 \times \mathrm{Mg} /(\mathrm{Mg}+\mathrm{Fe}) \geq 50$ and are interpreted to represent the host rock assemblage together with enstatite, $\mathrm{Cr}$-diopside, and Cr-pyrope. Other spinel populations are epigenetic and occur as mineral inclusions in enstatite, in the CMI, and 
as discrete grains and intergrowths in the intergranular space. These are distinguished based on compositional, textural, and genetic criteria as follows:

- Chromium spinels with increased $\mathrm{TiO}_{2}$ levels (1.11-7.19 wt\%; Spl1) are presented in association with titanate minerals either as mono- or polymineralic inclusions in enstatite (Figure $2 \mathrm{~d}-\mathrm{f}$ ) or as oxide intergrowths in the intergranular space (Figure 5a). The A-site occupancy varies from being either Mg-dominant (magnesio-chromite) in enstatite or Fe-dominant (chromite) in the intergranular space.

- Individual magnesio-chromite crystals up to $100 \mu \mathrm{m}$ in size are also recognized as distinct grains in the CMI (Spl2; Figure 3g,k).

- Titaniferous (1.76-7.61 $\mathrm{wt} \% \mathrm{TiO}_{2}$ ) aluminous chromite commonly forming individual crystals with an octahedral habit or grains closely associated with amphibole and phlogopite in kelyphite-like assemblages is observed in the intergranular space (Spl3; Figure $5 \mathrm{~b}, \mathrm{c}, \mathrm{f})$;

- Magnetite-ulvöspinel-chromite solid solution (Spl4) relatively poor in $\mathrm{Mg}(<10 \mathrm{wt} \% \mathrm{MgO}$ ) and $\mathrm{Al}$ $\left(<5 \mathrm{wt} \% \mathrm{Al}_{2} \mathrm{O}_{3}\right.$, but commonly less than $\left.1 \mathrm{wt} \%\right)$ is recognized as minor individual grains in the CMI and as intergrowths with other oxide minerals in the intergranular space (Figure 6d). This variety shows a range of compositions with varying proportions of $\mathrm{Fe}, \mathrm{Ti}$, and $\mathrm{Cr}$-specific end-members. In some cases relatively high $\mathrm{Mn}$ amounts (up to $2.78 \mathrm{wt} \% \mathrm{MnO}$ ) are observed in Spl4, reflecting the addition of jacobsite and manganochromite end-members;

- High-Al (36-47 $\mathrm{wt}_{\mathrm{t}}^{\mathrm{O}} \mathrm{Al}_{2} \mathrm{O}_{3}$ ) spinel (sensu stricto) demonstrating compositions typical for late-stage kimberlitic spinel varieties (pleonaste; Spl5) appears as individual grains up to $100 \mu \mathrm{m}$ in size in the intergranular space and as mantles on interstitial Spl3 (pleonaste reaction trend, [32,33]);

- $\quad$ Almost pure magnetite occurs as scatterings of fine specks in the CMI (Spl6; Figure 3h).

Rutile, $\mathrm{TiO}_{2}$, occurs as inclusions in enstatite, where it is intimately associated with ilmenite-geikielite, magnesio-chromite, clinopyroxene, pentlandite, and rare titanates of the magnetoplumbite and crichtonite groups. Rutile was also identified in the intergranular space of the orthopyroxenite as individual grains and intergrowths with a variety of Ti-rich oxide minerals, either identical to those occurring as inclusions in enstatite (see above) or phases genetically related to kimberlite, i.e., perovskite, geikielite (Ilm2 + Ilm3) and magnetite-ulvöspinel-chromite (Spl4) (Figures $5 \mathrm{a}$ and $6 \mathrm{~b}$ ). Inclusions of rutile in enstatite are $\mathrm{Cr}$-rich (up to $1.91 \mathrm{wt} \% \mathrm{Cr}_{2} \mathrm{O}_{3}$ ); intergranular rutile is also rich in $\mathrm{Cr}$ (up to $3.36 \mathrm{wt} \% \mathrm{Cr}_{2} \mathrm{O}_{3}$ ) and occasionally shows enrichment in high field strength elements(up to $4.26 \mathrm{wt} \% \mathrm{Nb}_{2} \mathrm{O}_{5}$, up to $0.77 \mathrm{wt} \% \mathrm{ZrO}_{2}$ ). Although Raman spectroscopic study has shown rutile to be the only $\mathrm{TiO}_{2}$ polymorph present in the sample (neither anatase nor brookite have been identified), we suggest rutile to occur as two generations (Rt1 and Rt2) based on its paragenetic affinity to two distinct mineral assemblages.

The studied crichtonite-group minerals, $\mathrm{ABC}_{18} \mathrm{~T}_{2} \mathrm{O}_{38}$, and magnetoplumbite-group minerals, $\mathrm{AB}_{12} \mathrm{O}_{19}$, are rare chromium titanates enriched in a number of incompatible elements $(\mathrm{Ba}, \mathrm{K}, \mathrm{Ca}, \mathrm{Sr}, \mathrm{Zr}$, rare earths) [34-37]. In the orthopyroxenite, the rare titanates are found as abundant inclusions in enstatite (Figure 1c,d and Figure $2 \mathrm{~d}-\mathrm{f}$ ). Crichtonite-group minerals also have a characteristic manifestation in the form of strongly inhomogeneous intergrowths with rutile (Rt1), chromite (Spl1), and Mg-ilmenite (IIm1) localized in the intergranular space of the rock (Figure 5a). Minerals of the crichtonite group are represented in enstatite by Fe-dominant in the B site analogues of lindsleyite (Ba) and mathiasite $(\mathrm{K})$, whereas within the interstitial oxide intergrowths crichtonite-group minerals show a spectacular array of site occupancies, appearing as lindsleyite (sensu stricto), Ca-Zr-specific mineral loveringite, low-Zr high-Fe counterparts of lindsleyite and loveringite, and Sr-dominant species (not approved yet by IMA). Magnetoplumbite-group minerals are represented by typical for the upper mantle K-Ba yimengite-hawthorneite (YIHA) solid solution [36-38]. However, for the studied grains of yimengite-hawthorneite, an increased amount of $\mathrm{Al}_{2} \mathrm{O}_{3}$ (5.74-7.69 wt.\%) is characteristic. The peculiarities of the morphology and chemistry of the rare titanates examined have been reported in more detail in our previous publication [27]. 
Perowskite, $\mathrm{CaTiO}_{3}$, is a characteristic constituent of the CMI (Figure 3c,d), and also occurs in composite intergranular intergrowths together with a variety of oxide minerals (Figure $6 b, d$ ). Compositional variations in perovskite result chiefly from differing concentrations of rare elements (large ion lithophile, LILE, high field strength, HFSE, and light rare earth elements, LREE). $\mathrm{LREE}_{2} \mathrm{O}_{3}$ ( where $\mathrm{LREE}=\mathrm{La}, \mathrm{Ce}, \mathrm{Pr}, \mathrm{Nd}$ ) varies from 0.33 to $5.77 \mathrm{wt} \%$ and $\mathrm{Nb}_{2} \mathrm{O}_{5}$ lies within 1.08 and $5.50 \mathrm{wt} \%$. $\mathrm{Na}_{2} \mathrm{O}$ is rather high at $0.83-2.95 \mathrm{wt} \%$. Perovskite grains are often inhomogeneous; where zoned, they display a general trend of rimward increase in LREE, $\mathrm{Na}$, and $\mathrm{Nb}$. According to the SEM EDS data and X-ray elemental mapping (Figure $6 \mathrm{~d}, \mathrm{~g}, \mathrm{j}$ ), the very margin (measuring 1-3 $\mu \mathrm{m}$ ) of the zoned grains shows the highest LREE ( $>6 \mathrm{wt} \%), \mathrm{Na}_{2} \mathrm{O}(5.6 \mathrm{wt} \%), \mathrm{Nb}_{2} \mathrm{O}_{5}(12.9 \mathrm{wt} \%)$, and $\mathrm{Ta}_{2} \mathrm{O}_{5}(1.5 \mathrm{wt} \%) . \mathrm{SrO}$ in the perovskite grains is generally low (0.33-0.78), although may be higher toward the rims (up to $2.05 \mathrm{wt} \%)$. Th occurs only as minor component in the LREE-Nb-Na-rich perovskite rims. $\mathrm{ZrO}_{2}$ in the perovskites is negligible $(<0.30 \mathrm{wt} \%)$ and $\mathrm{Fe}_{2} \mathrm{O}_{3}$ does not exceed $1.36 \mathrm{wt} \%$.

Unlike LILE-bearing complex titanates of the magnetoplumbite and crichtonite groups, the hollandite-group minerals, priderite, $\mathrm{KFe}^{3+} \mathrm{Ti}_{7} \mathrm{O}_{16}$, and redledgeite, $\mathrm{BaCr}^{3+}{ }_{2} \mathrm{Ti}_{6} \mathrm{O}_{16}$, are restricted to the intergranular space of the rock. In the examined sample priderite is very rare; it forms irregularly shaped small $(<7 \mu \mathrm{m})$ grains, at places intensively rimmed by redledgeite (Figure 5e). Priderite contains appreciable amounts of chromium (2.39-2.50 wt $\left.\% \mathrm{Cr}_{2} \mathrm{O}_{3}\right)$, which is a typical substitute for $\mathrm{Fe}^{3+}$ in natural priderites [39-41]. Redledgeite is a very rare barium-chromium titanate of the hollandite supergroup, priderite subgroup [42]. Apart from the type findings in the Red Ledge mine, California, USA [43-48], there are very few reports concerning redledgeite (sensu stricto) occurrences in the world [49-51]. Redledgeite constitutes composite oxide intergrowths with Mn-enriched geikielite, Fe-Ti-Cr spinel, perovskite and rutile; here redledgeite is generally confined to the outer part of the aggregates, penetrating inside the geikielite matrix as irregularly shaped or acicular thin veinlets (Figure $6 \mathrm{~b}, \mathrm{c})$. Another indicative occurrence of redledgeite is as thin $(<10 \mu \mathrm{m})$ discontinuous fringes on earlier-formed rutile, Cr-spinel, and priderite (Figure 5e-h). Rare small (1-10 $\mu \mathrm{m})$ individual prismatic crystals or anhedral grains of redledgeite (Figure $5 \mathrm{~d}$ ) are dispersed along the interstices, cropping out from the matrix composed of phlogopite, tetraferriphlogopite, Al-poor potassic amphiboles, serpentine, and calcite. The chemical composition of redledgeite is characterized by the presence of a significant $\mathrm{K}_{2} \mathrm{O}(0.58-2.66 \mathrm{wt} \%)$, which reflects the contribution of the potassium endmembers of the hollandite supergroup to the natural solid solution examined here. Comparatively high (0.15-2.97 wt\%) $\mathrm{Nb}_{2} \mathrm{O}_{5}$ concentrations are recognized in a number of redledgeite grains, probably resulting from the coupled isomorphic substitution $2 \mathrm{Ti}^{4+}=\mathrm{Cr}^{3+}+\mathrm{Nb}^{5+}$ typical for other Ti-rich minerals, e.g., rutile [17,52-55]. Other analyzed elements, supposed to enter either tunnel $(\mathrm{Na}, \mathrm{Sr}, \mathrm{La}, \mathrm{Ce}, \mathrm{Pb})$ or octahedral $(\mathrm{Mn}, \mathrm{Zr}, \mathrm{Al}$, $\mathrm{Ta}, \mathrm{Si}$ ) sites are presented in minor or non-detectable amounts. Insufficient analytical totals (97.5-98.5 $\mathrm{wt} \%$ ) of redledgeite analyses are attributed to result from the presence of an unaccounted amount of volatile component. Water may accompany LILE in the tunnel sites of the hollandite-type titanates and be present in their framework structure as hydroxyl ion as well $[47,56,57]$.

\subsubsection{Carbonates}

Calcite, $\mathrm{CaCO}_{3}$, is common in the $\mathrm{CMI}$ and occurs here as acute to obtuse rhombohedral crystals up to $200 \mu \mathrm{m}$ across (Figure $3 \mathrm{~d}, \mathrm{~g}, \mathrm{k}$ ) and as finely crystalline mosaic-like aggregates (Figure 3e). Both calcite morphologies occur intimately close or within the serpentine matrix. Note that a calcite crystal poikilitically encloses an olivine grain (Figure 3d) and another one forms an intergrowth with phlogopite (Figure 3g). Thus, the calcite occurring in the CMI is likely a primary igneous phase (Cal1). One exception is the calcite occurring in a CMI together with kuliginite and iowaite and forming an intergrowth with the latter (Figure 3i); here the calcite is probably secondary (hydrothermal; Cal2). In the intergranular space calcite occurs together with serpentine (Figure $5 \mathrm{~d}$,e); whether it is Cal1 or Cal2 remains uncertain. Cal1 in all the habits is rather pure ( $<1 \mathrm{wt} \% \mathrm{MgO}$ and $<0.5 \mathrm{wt} \% \mathrm{FeO})$; however, admixtures of $\mathrm{BaO}$ (up to $0.39 \mathrm{wt} \%$ ) and $\mathrm{SrO}$ (up to $0.63 \mathrm{wt} \%$ ) are common. Another polymorph of $\mathrm{CaCO}_{3}$, aragonite, has not been identified by Raman measurements. Dolomite, $\mathrm{CaMg}\left(\mathrm{CO}_{3}\right)_{2}$, was found 
only in a single CMI as irregularly shaped aggregate set in a serpentine matrix. It contains $2.26 \mathrm{wt} \%$ $\mathrm{FeO}$ and $0.88 \mathrm{wt} \% \mathrm{MnO}$.

\subsubsection{Sulfides}

Pentlandite, $(\mathrm{Fe}, \mathrm{Ni})_{9} \mathrm{~S}_{8}$, is recognized as small $(1-30 \mu \mathrm{m})$ particles and globules in enstatite (Figures $1 \mathrm{~d}$ and $2 \mathrm{f}$ ), in the CMI (Figure 3e,k) and in the rock interstices (Figure 5j). Enstatite-hosted pentlandite is close to stoichiometry (Pn1), whereas a substantial impurity of cobalt (up to $16.1 \mathrm{wt} \% \mathrm{Co}$ ) is observed in the variety appearing in the CMI (Pn2). Hence, we expect pentlandite to occur as at least two distinct generations based on the textural and compositional differences. Pyrrhotite, $\mathrm{Fe}_{(1-\mathrm{x})} \mathrm{S}(\mathrm{x} \leq 0.17)$, was identified as a rare mineral in the intergranular space, intimately associated with pentlandite and djerfisherite (Figure 5j). Djerfisherite is a Cl-bearing potassium sulfide, $\mathrm{K}_{6}(\mathrm{Fe}, \mathrm{Ni}, \mathrm{Cu})_{25} \mathrm{~S}_{26} \mathrm{Cl}$, found in alkaline ultramafites and carbonatites, as well as in mantle xenoliths carried out by kimberlite melts ([58] and references therein). In the studied orthopyroxenite, djerfisherite forms small (5-30 $\mu \mathrm{m})$ grains in the CMI and rock interstices, occasionally in intergrowths with pre-existing sulfides (Figure 3e, 5j). Djerfisherite contains ( $w \mathrm{t} \%$ ) 41.0-43.9 Fe, 7.7-13.0 Ni, 1.29-5.06 Cu, up to 0.60 Co, 8.69-9.3 K, 32.9-33.2 S, $1.26-1.37 \mathrm{Cl}$.

\subsubsection{Sulfate}

Barite, $\mathrm{BaSO}_{4}$, occurs as small specks $(<10 \mu \mathrm{m})$ in the interstitial space, where it is often associated with Al-poor alkali amphiboles (Figure 5i). In rare cases, barite occurs as coronas on interstitial grains of Ba-bearing crichtonite-group mineral. Numerous minute $(<3 \mu \mathrm{m})$ grains of barite are recognized in the CMI as well. Barite is close to stoichiometric composition, yet in some examples it contains appreciable amounts of $\mathrm{SrO}$ (up to $3.48 \mathrm{wt} \%$ ).

\subsubsection{Phosphates}

Apatite, $\mathrm{Ca}_{10}\left[\mathrm{PO}_{4}\right]_{6}(\mathrm{~F}, \mathrm{Cl}, \mathrm{OH})_{2}$, is one of the indicative constituents of the CMI, where it commonly appears as individual euhedral bipyramidal and hexagonal crystals set in the serpentine pools (Figure 3b-e,h). In most cases, but not necessarily, apatite crystallized at the margins of the pools just near the olivine crystals that frame the serpentine. At places, apatite occurs in interstitial space of the rock (Figure 5j), commonly forming crystals at the margin between serpentine and diopside; here it is closely associated with tetraferriphlogopite (Tphl2) and K-richterite. In the interstitial intergrowths apatite is found as irregular grains and hexagonal prisms (Figure $6 \mathrm{~b}, \mathrm{~d}$ ) together with perovskite, geikielite (Ilm2), rutile (Rt2), magnetite-ulvöspinel-chromite (Spl4), phlogopite, and serpentine. The examined apatites are hydroxy-fluor species containing 0.55-1.20 apfu of fluorine. $\mathrm{CaO}$ and $\mathrm{P}_{2} \mathrm{O}_{5}$ concentrations vary in the ranges of $52.6-55.2$ and $39.7-41.3 \mathrm{wt} \%$, respectively. The difference between the apatite recognized in the CMI and interstitial one is subtle; yet it can be established based on the abundance of chlorine and LREE $\left(\mathrm{La}_{2} \mathrm{O}_{3}+\mathrm{Ce}_{2} \mathrm{O}_{3}\right)$. The apatite in the CMI is almost free of chlorine and LREE (up to 0.05 and $0.15 \mathrm{wt} \%$, respectively), whereas the interstitial grains demonstrate appreciably higher $\mathrm{Cl}$ and LREE amounts at the levels of 0.07-0.21 and 0.13-0.77 wt\%, respectively. Moreover, the inclusion-hosted apatite is either hydroxyl- or fluorine-dominant, whereas the interstitial variety has been established as being only hydroxyl-dominant. Apart from the above mentioned differences, the apatites are roughly similar in chemistry; in both textural varieties strontium is a ubiquitous substitute for calcium and falls between 0.20 and $1.50 \mathrm{wt} \% \mathrm{SrO}$. Other substitutes include $\mathrm{Fe}(0.09-0.32 \mathrm{wt} \% \mathrm{FeO})$ and $\mathrm{Na}\left(0.01-0.41 \mathrm{wt} \% \mathrm{Na}_{2} \mathrm{O}\right.$ ) for $\mathrm{Ca}$, and $\mathrm{Si}$ (up to $0.28 \mathrm{wt} \% \mathrm{SiO}_{2}$ ) for $\mathrm{P}$. $\mathrm{BaO}$ does not exceed $0.05 \mathrm{wt} \%$. Despite some differences in chemistry, the apatites do not appear to represent two distinct populations, since the compositions of both textural varieties correspond well to those of typical magmatic (i.e., kimberlitic) apatites, although kimberlitic apatites may appear more enriched in Si [33,59].

The study of $\mathrm{Ba}-\mathrm{Na}-\mathrm{Mg}$ phosphate has proven challenging because of its uncertain mineral identity and small size $(<10 \mu \mathrm{m})$ of grains. Ba-Na-Mg phosphate grains are usually found together with apatite in a K-richterite matrix in the intergranular space of the rock. Other associated minerals 
are olivine and antigorite. The mineral forms particles of irregular shape, occasionally intergrown with apatite, as well as a crystal of hexagonal morphology, which may also be a tabular trigonal crystal cross-cut parallel to the basal plane (001) (Figure 5k). Based on SEM EDS data, the mineral contains $(\mathrm{wt} \%) \sim 33 \mathrm{BaO}, \sim 15 \mathrm{Na}_{2} \mathrm{O}, \sim 11 \mathrm{MgO}, \sim 35 \mathrm{P}_{2} \mathrm{O}_{5}$, which approximately corresponds to a crystal-chemical formula $\mathrm{Na}_{2} \mathrm{BaMg}\left(\mathrm{PO}_{4}\right)_{2}$. SrO is also present at the levels of 2.19-2.24 wt\%, with $\mathrm{Sr}$ likely substituting for Ba. A mineral with a similar composition has been described in the ultrapotassic dyke Kvalöya, Norway [60]. This mineral is presumably a natural analogue of synthetic orthophosphate, $\mathrm{Na}_{2} \mathrm{MgBa}\left(\mathrm{PO}_{4}\right)_{2}$, which has possible optical applications [61]. It can be also considered as a Ba-analogue of brianite, $\mathrm{Na}_{2} \mathrm{CaMg}\left(\mathrm{PO}_{4}\right)_{2}$ [62], and $\mathrm{Mg}$-analogue of iwateite, $\mathrm{Na} 2 \mathrm{BaMn}\left(\mathrm{PO}_{4}\right)_{2}$ [63]. The Raman spectrum of this phosphate mineral is presented in Figure $7 \mathrm{~g}$.

\subsubsection{Oxyhydroxides and Hydroxyhalides}

Goethite, $\mathrm{Fe}^{3+} \mathrm{O}(\mathrm{OH})$, occurs as reniform and botryoidal accumulations, which are encountered in the interstitial space of the rock (Figure 5l). Hydroxyhalides of iron, kuliginite, $\mathrm{Fe}_{3} \mathrm{Mg}(\mathrm{OH})_{6} \mathrm{Cl}_{2}$ [64], and iowaite, $\mathrm{Mg}_{4} \mathrm{Fe}^{3+}(\mathrm{OH})_{8} \mathrm{OCl} \cdot 3\left(\mathrm{H}_{2} \mathrm{O}\right)$, are present in the CMI as secondary minerals (Figure 3i). Kuliginite is found as aggregates of small $(<5 \mu \mathrm{m})$ crystals (distinctively whitish in BSE compared to iowaite) deposited onto the serpentine-calcite matrix. Under a binocular microscope, kuliginite is characteristically orange-brown to rubiginous in color. Kuliginite contains significant amounts of $\mathrm{MnO}$ (1.95-5.62 wt\%). Iowaite forms distinct tabular and platy crystals up to $50 \mu \mathrm{m}$ in size with recognizable cleavage planes (Figure 3i). These are set in a serpentine pool and are intergrown with calcite.

\section{Discussion}

\subsection{The Genesis of Minerals: Evidence for the Superimposed Nature}

The examined variety of epigenetic minerals showing such contrasting compositions and modes of occurrence unequivocally indicates that throughout its prolonged history the orthopyroxenite underwent a series of superimposed metasomatic processes. It should be noted that long before the crystallization of the first newly formed minerals of external origin, the orthopyroxenite system had experienced the solid solution breakdown of the high-T orthopyroxene precursor with the formation of exsolved clinopyroxene and magnesio-chromite, as indicated by the numerous morphologically oriented inclusions of these minerals in enstatite. Clinopyroxene, magnesio-chromite and vein-like garnet grains, which are distributed in subordinate amounts around the enstatite crystals, seem to be of exsolution origin as well, as documented in some global orthopyroxenite occurrences [65,66]. Later, the orthopyroxenite served as a natural substrate for crystallization of various minerals that are united by the fact that they are epigenetic with respect to the host rock and crystallized from passing liquids. The formation of these minerals, though, occurred at completely different time spans. We distinguish at least three distinct processes that have been responsible for the formation of the identified suite of minerals. An affiliation of each studied mineral to a specific process during the orthopyroxenite evolution is given in Table 1.

\subsection{Stage 1: Deep-Seated Mantle Metasomatism}

Inclusions of mantle chromium titanates of the magnetoplumbite and crichtonite groups in enstatite indicate that during its residence in the lithospheric mantle, the orthopyroxenite underwent the influx of a metasomatic liquid charged with high concentrations of Ti and incompatible elements (Stage 1 in Table 1). Crichtonite-group minerals and YIHA series are widely represented in metasomatized mantle xenoliths the world over and are characteristic indicators of metasomatic enrichment of lithospheric mantle assemblages by deep-sourced melts or fluids [17,27,30,36-38,67-73]. The extreme enrichment of the enstatite-hosted titanates in LILE, HFSE, and REE could have been caused only by the introduction of these elements into the system during the metasomatism [27]. The propagation of the metasomatic agent proceeded along cracks and other weakened zones of enstatite such as cleavage planes. During 
this process, the crystallization of the rare titanates took place presumably on fine Cr-spinel lamellae, the latter acting as nucleation centers. The first deep-sourced metasomatic event also involved the crystallization of rutile (Rt1), ilmenite-geikielite (Ilm1), Cr-spinel (Spl1), and pentlandite (Pn1), which are recognized together with the rare titanates in enstatite, and also have manifestations in the form of individual grains and intergrowths in the intergranular space of the rock. Na-enriched Cpx 1 is related to Stage 1 as well, likely formed as a product of re-crystallization and coalescence of fine exsolution lamellae. At this stage of the research, the age of such a metasomatic event cannot be reliably established; it could be very ancient, as well as approach the age of kimberlite magmatism, showing a genetic link with the latter as proposed in [1,74].

\subsection{Stage 2: Infiltration and Evolution of A Kimberlite-Related Melt}

The second metasomatic episode (Stage 2 in Table 1) reflects the effect of a kimberlite-related melt on the orthopyroxenite, which is clearly indicated by the presence of phases typical of kimberlite both in the CMI and in the intergranular space of the rock (olivine, phlogopite, tetraferriphlogopite, ilmeniteand spinel-group minerals, rutile, perovskite, djerfisherite, pentlandite, pyrrhotite, calcite, apatite). The second stage is assumed as being directly related to the eruption of the Udachnaya kimberlite magmas during the Middle Paleozoic episode ( 360 Ma) of kimberlite magmatism on the Siberian platform [75].

\subsubsection{Occurrences of Kimberlite-Related Minerals in Global Mantle Xenoliths}

It is believed that all mantle xenoliths are invaded and contaminated to a varying extent by transporting kimberlite melts. In some examples, mass balance calculations established the discrepancies between the calculated and analyzed amounts of incompatible elements in mantle-derived fragments. Schmidberger and Francis [2] recognized significant LREE deficiencies in peridotite xenoliths from the Nikos kimberlite pipe, Somerset Island, Canada, and attributed this mismatch to the presence of small amounts of kimberlite material in the intergranular space. Likewise, by studying lherzolite xenoliths from several well-known kimberlite pipes of the Kaapvaal craton (South Africa), Grégoire et al. [4] argued that "a significant budget of the most highly incompatible elements is located in cracks, along the grains boundaries, in secondary minerals and/or in fluid inclusions." These assumptions were further confirmed by studying unaltered xenoliths of sheared peridotites from non-serpentinized kimberlites of the Udachnaya-East pipe [16]. The following accessory minerals have been found in the intergranular space of these xenoliths: olivine, clinopyroxene, monticellite, sodalite, phlogopite, tetraferriphlogopite, humite-clinohumite-group minerals, chromite, magnetite, perovskite, apatite, aragonite, calcite, pentlandite, pyrrhotite, and djerfisherite [16]. For the same suite of xenoliths, it was also shown that the calculated whole-rock LILE and HFSE abundances are an order(s) of magnitude lower than those measured. The addition of up to $2 \mathrm{wt} \%$ of the host kimberlite to the calculated composition showed the identity of the model sample composition to the analyzed one [5]. The presence of such an interstitial mineral association in these xenoliths was interpreted to result from the infiltration of a Cl-S- $\mathrm{CO}_{2}$-rich kimberlite melt into mantle rocks attended by numerous reactions between the melt and rock-forming silicates.

\subsubsection{Pressure-Temperature and Time Constraints on the Crystallization of Stage 2-Related Minerals}

The two minerals examined, calcite and djerfisherite, allow to unambiguously prove the linkage between the Stage 2-related assemblage and kimberlite magmatism. Within the lithospheric mantle beneath Udachnaya the studied xenolith resided at $\sim 80{ }^{\circ} \mathrm{C}$ and $\sim 35 \mathrm{kbar}$ [27], which corresponds to the stability field of aragonite [76]. However, so far we have recognized only the low pressure-high temperature $\mathrm{CaCO}_{3}$ polymorph, calcite, to be present in the CMI. Based on the position of the calcite-aragonite transition line, calcite in the orthopyroxenite xenolith could have crystallized only at pressures below $\sim 2 \mathrm{GPa}$, i.e., after the xenolith had been carried by a transporting melt to shallower depths. 
Djerfisherite is a common mineral crystallizing during late stages of kimberlite melt evolution; it has also been identified in kimberlite-borne xenoliths (see review in [58]). In particular, djerfisherite was repeatedly found in the Udachnaya-East pipe among the groundmass minerals of various units of kimberlites [12,77-79] and as a daughter mineral inside primary and secondary melt inclusions in the groundmass kimberlite minerals [13,80-82]. It also occurs in the intergranular space of various mantle xenoliths $[15,16]$ and as a daughter mineral inside the secondary melt inclusions in olivine from sheared peridotite xenoliths [16,20,22]. However, experiments performed by Sharygin et al. [83] showed that djerfisherite is not stable at temperature and pressure values above $800{ }^{\circ} \mathrm{C}$ and $3 \mathrm{GPa}$, respectively. Thus, as noted in [58], "it is unlikely that djerfisherite is a stable in situ phase that formed in the deep mantle." In xenoliths of diamondiferous eclogites [15] and sheared peridotites [16] from the Udachnaya-East pipe, the presence of djerfisherite in the interstitial space has been attributed to interaction of the xenoliths with a transporting kimberlite melt. In secondary melt inclusions in olivine from the sheared peridotites, djerfisherite has been interpreted to crystallize directly from a primitive kimberlite melt [20,22].

Thus, calcite and djerfisherite appear to have originated from liquid that was present in the sample during xenolith transportation to the surface, with ambient $\mathrm{P}-\mathrm{T}$ parameters of the crystallization being lower than those during in situ residence of the xenolith in the mantle. Whether this liquid was primitive kimberlite melt propagating upwards through the mantle substrate, melt derived from so-called failed eruption attempts [84], or melt that eventually formed the Udachnaya pipe $[15,16]$, remains debatable. We address the problem of melt composition in more details in Section 4.3.4.
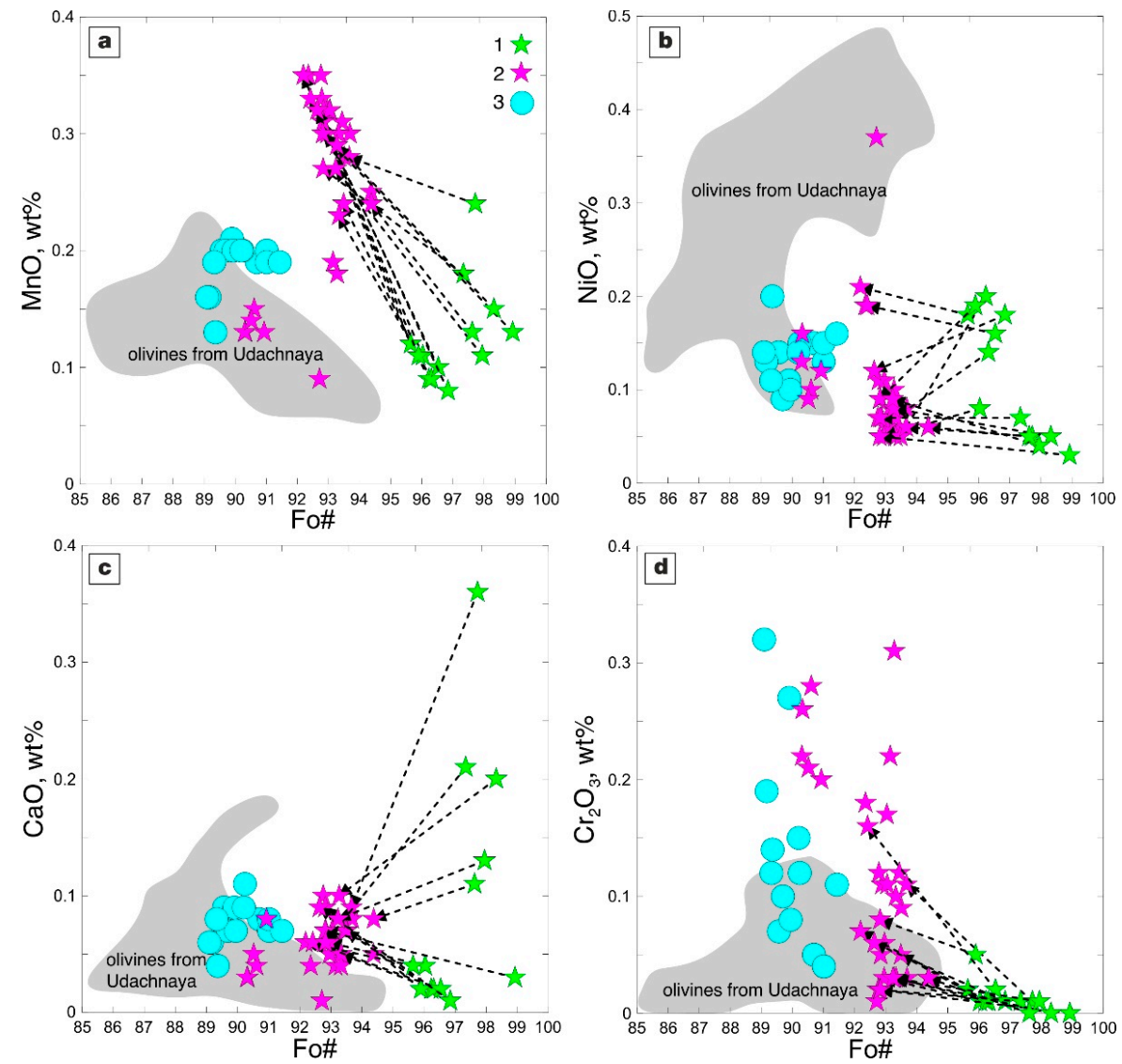

Figure 8. (a-d) Co-variation diagrams for olivine grains in the orthopyroxenite. 1-Cores of zoned grains in the crystallized melt inclusions, 2-Rims of zoned grains and homogeneous crystals in the crystallized melt inclusions; 3-Grains in the intergranular space of the rock. Field "Olivines from Udachnaya" comprises published analyses of phenocrystic/xenocrystic olivine and olivine in mantle xenoliths from the Udachnaya kimberlite pipe after [85-91]. 
Further evidence for the linkage between the identified suite of minerals and kimberlite magmatism lies in zoning of the examined phases. We have identified zoned grains of olivine, phlogopite, tetraferriphlogopite, ilmenite, spinel and perovskite. Furthermore, interstitial oxide intergrowths are very inhomogeneous even on a scale of microns (Figure 6). The detailed investigation of compositional profiles is beyond the scope of this work, but it is obvious that such inhomogeneity cannot be maintained for a long geological time under mantle $\mathrm{P}-\mathrm{T}$ conditions. These lines of evidence confirm that the recognized suite of minerals attributed here to Stage 2 is indeed of kimberlitic affinity.

\subsubsection{Compositional Evolution of Stage 2-Related Minerals}

The cores of olivine crystals examined in the CMI show Mg\# varying from 95.6 to 98.9. Such MgO-rich (55-56 wt\%) olivine has been identified previously neither among olivines from Udachnaya mantle xenoliths [85-89] nor among xenocrystic/phenocrystic olivine [90,91] from kimberlites of the Udachnaya-East pipe (Figure 8). Among olivine xenocrysts/phenocrysts from global kimberlites samples with Fo $>95$ are exceptionally rare [92]. We suggest that such uncommon composition was produced owing to incongruent nature of the reaction between enstatitic orthopyroxene and kimberlite melt, i.e., Opx + kimberlite melt $\rightarrow \mathrm{Ol}_{\text {core }}(\mathrm{Mg \#} \mathrm{96-99)}+$ hybrid melt. In the meanwhile, the marginal zones of the olivine with $\mathrm{Mg \#}=90.3-94.4$ fall into a typical compositional range of both olivine from mantle xenoliths in Udachnaya and olivine as xenocrysts/phenocrysts from kimberlites of the pipe [85-91] (Figure 8). Interstitial olivine grains with Fo 89.1-91.4 are again well within the range of Fo in the previously studied olivines from Udachnaya (Figure 8).

Of particular interest is the distribution of minor elements $(\mathrm{Mn}, \mathrm{Cr}, \mathrm{Ca}, \mathrm{Ni})$ in the olivines from the orthopyroxenite examined here. It is notable how the compositions of olivine evolve from core to rim toward the common points (Figure 8). The concentrations of $\mathrm{CaO}$ and $\mathrm{NiO}$ evolve strictly toward the field of olivine compositions from Udachnaya (a single outcast with high $\mathrm{NiO}=0.37 \mathrm{wt} \%$ is the largest homogeneous grain likely formed at depth; Figure 8b). However, in the case of $\mathrm{Mn}$ and $\mathrm{Cr}$, the patterns are more complicated. The Mn concentrations in the rims of zoned crystals are higher than the field of olivines from Udachnaya, whereas the compositions of homogeneous crystals in the CMI and interstitial olivine grains either approach, or fall within the field of Udachnaya olivines. Conversely, the abundances of chromium evolve toward the Udachnaya field from core to rim of the zoned crystals, while homogeneous crystals and interstitial grains show a scatter toward higher $\mathrm{Cr}$ values. The observed variations are likely controlled by a changing partitioning behavior of minor elements during olivine crystallization, which, in turn, appears to be a complex function of at least three parameters, i.e., evolving composition of the hybrid melt, buffering from co-crystallizing $\mathrm{Ni}, \mathrm{Cr}$, and Mn-bearing phases (such as spinel- and ilmenite-group minerals) and progressive change in $\mathrm{P}-\mathrm{T}$ parameters during kimberlite melt ascent [92-94].

The chemistry of the Stage 2-related ilmenite-group minerals $(I \operatorname{lm} 2, \operatorname{Ilm} 3)$ is indicative of changes in the bulk composition of the parent magma. Inhomogeneous geikielite showing progressive enrichment in $\mathrm{Mg}(\operatorname{Ilm} 2)$ is thought as being related to the re-equilibration with the evolving kimberlite magma in accordance with a typical magmatic trend established in many kimberlites worldwide ([33] and references therein). However, these inhomogeneous grains also show notable enrichment in $\mathrm{MnO}$ $(1.4-4.7 \mathrm{wt} \%$ ), though not so pronounced as is observed in $\operatorname{Ilm} 3$ (up to $17.2 \mathrm{wt} \%$ ). The development of Mn-rich ilmenite in mantle-derived rocks is commonly attributed to late-stage subsolidus replacement of an earlier-formed ilmenite [33,41,95,96], defined by Mitchell [33] as kimberlite reaction trend. However, the exact process which gives rise to the formation of Mn-rich ilmenite is debated, with the probable scenarios summarized in [96]. Our data indicate that the Mn-rich ilmenite (IIm3) is definitely the latest among all the ilmenite populations, since it occurs only as thin mantles on Ilm2. We suppose that these rims were formed as culmination of the kimberlitic reaction trend [33] with the participation of late-stage portions of a hybrid kimberlite melt rather than with the participation of external fluids and groundwaters. 
The evolution of spinel is believed to proceed throughout kimberlite crystallization [32,33] and is controlled by a combination of variables summarized in [32]. In the sample featured here we have distinguished four spinel-group species that are related to the kimberlite magmatism (Spl2, $S p l 3, S p l 4, S p l 5)$. Aluminous magnesio-chromite in the CMI (Spl2) and chromite (Spl3) crystals in interstices are likely to represent early generation phases. Subsequently, these compositions evolved to magnetite-ulvöspinel-chromite compositions with low concentrations of $\mathrm{Mg}$ and $\mathrm{Al}$ (Spl4). This change of spinel chemistries corresponds to the magmatic Trend 2 described in [32,33]. The final product of this evolution is known as almost pure magnetite. However, we have not identified magnetite rims on any of the inhomogeneous spinel grains, and thus we interpret the small magnetite specks recognized in a serpentine matrix (Figure $3 \mathrm{~h} ; \boldsymbol{S p l 6}$ ) as products of retrograde olivine serpentinization under relatively oxidizing conditions, during which iron was released [33]. Thus, magnetite is likely related to hydrothermal Stage 3, rather than to the infiltration of a kimberlite-related melt.

An increase in titanium and ferric iron in the original chromium spinel during the evolution of kimberlitic media is suggested to be caused by the co-crystallization of $\mathrm{Mg}$ - and Al-rich silicate minerals, especially phlogopite [32,33]. The extensive development of phlogopite in the CMI testifies to the preferential fractionation of $\mathrm{Al}$ into the phlogopite. On the other hand, the occurrence of tetraferriphlogopite in the same melt droplets indicates that at a certain point the phlogopite ceased to crystallize because of the $\mathrm{Al}$ deficiency in the melt. The latter could have been caused by the onset of the Al-rich pleonaste (Spl5) crystallization during the late stages of kimberlite evolution.

The studied perovskite crystals exhibit inverse pattern of intergranular zonation (i.e., increase in LREE, $\mathrm{Na}, \mathrm{Nb}$, Th toward the rim) compared with most perovskites from kimberlites $[97,98]$. However, similar pattern to the one described here has been also recognized in global kimberlites, e.g., in perovskites from the Lac de Gras and Grizzly kimberlites, Canada [98,99]. Chakhmouradian and Mitchell [99] interpreted such perovskites to result from the interaction of early, compositionally primitive generations of this mineral with a deuteric fluid or melt enriched in incompatible elements. The perovskites studied here are progressively enriched in incompatible components rimward and the highest concentrations of LREE, $\mathrm{Na}, \mathrm{Nb}$, Th are observed at the very thin outermost mantles, with the latter likely formed from late portions of a hybrid kimberlite melt. The existence of late-stage derivates of a hybrid melt enriched in Na, LILE (Ba, Sr, K), HFSE (Nb, Ta), and REE ( $\mathrm{La}, \mathrm{Ce}, \mathrm{Pr}, \mathrm{Nd}$ ) in the system "orthopyroxenite-kimberlite melt" is also supposed based on the occurrences of several other minerals rich in trace elements, such as redledgeite, Ba-Na-Mg phosphate, and barite.

\subsubsection{Orthopyroxene Dissolution and Implications for Melt Composition}

Among mantle silicates, orthopyroxene shows the strongest ability for rapid and preferential dissolution in melts of various compositions ([100] and references therein). It is widely noted that in kimberlite rocks orthopyroxene xenocrysts are quite rare with respect to other xenocrysts of mantle silicate minerals and always exhibit traces of resorption (e.g., $[94,101,102])$; the same holds true for kimberlites of the Udachnaya pipe [103]. Likewise, the examined here CMI and reaction zones between them and host orthopyroxene indicate orthopyroxene dissolution during capturing of the melt droplets (Figures 3 and 4).

Bowen and Andersen [104] were the first to establish that in the binary system $\mathrm{MgO}-\mathrm{SiO}_{2}$ enstatite breaks down at $1559{ }^{\circ} \mathrm{C}$ and $1 \mathrm{kbar}$ to form forsterite $+\mathrm{SiO}_{2}$. Later, a series of experiments on the dissolution of orthopyroxene in carbonatite melts of various compositions at different $\mathrm{P}-\mathrm{T}$ parameters was carried out. Some examples of the essential reactions established by these experimental works are as follows:

$$
\text { Opx }+ \text { dolomitic carbonate melt } \rightarrow \mathrm{Ol}+\mathrm{Cpx}+\mathrm{CO}_{2} \uparrow \text { (free fluid phase) }
$$

$$
\left(1.5-2.5 \mathrm{GPa}, 960-1200{ }^{\circ} \mathrm{C}\right)[105]
$$

Opx + K-Na- $\mathrm{H}_{2} \mathrm{O}$-rich dolomitic carbonate melt $\rightarrow \mathrm{Ol}+\mathrm{Cpx}+\mathrm{Phl}+\mathrm{CO}_{2} \uparrow$ (free fluid phase) 


$$
\begin{gathered}
\left(2.0 \mathrm{GPa}, 1000{ }^{\circ} \mathrm{C}\right)[106] \\
\mathrm{Opx}+\mathrm{Na}_{2} \mathrm{CO}_{3} \text { melt } \rightarrow \text { Na-Si-Mg hybrid melt }+\mathrm{CO}_{2} \uparrow \text { (free fluid phase) } \\
\left(1 \mathrm{~atm}, 1000-1100^{\circ} \mathrm{C}\right)[107] \\
\mathrm{Opx}+\mathrm{Na}_{2} \mathrm{CO}_{3} \text { melt } \rightarrow \mathrm{Ol}+\text { Krinovite }+ \text { carbonate melt }+\mathrm{CO}_{2} \text {-rich silicate melt } \\
\left(2 \mathrm{GPa}, 1000^{\circ} \mathrm{C}\right)[108] \\
\mathrm{Opx}+\mathrm{Na}_{2} \mathrm{CO}_{3} \text { melt } \rightarrow \mathrm{Ol}+\text { carbonate melt }+ \text { silicate melt }
\end{gathered}
$$

$$
\left(2 \mathrm{GPa}, 1100-1200^{\circ} \mathrm{C}\right)[100] .
$$

Pilbeam et al. [94] suggested the following reaction to account for olivine crystallization, orthopyroxene dissolution, and the calcite dominated groundmass of the Majuagaa kimberlite, Southern West Greenland:

$$
\begin{gathered}
\text { Opx }+ \text { dolomitic component in melt } \rightarrow \mathrm{Ol}+\mathrm{Cal}+\mathrm{CO}_{2} \uparrow \\
\text { (free fluid phase) [94]. }
\end{gathered}
$$

Recently, the following reaction has been proposed based on the PERPLE_X modeling:

$$
\text { Opx }+ \text { Mg-Tschermak's component in Opx }+\left[\mathrm{K}_{2} \mathrm{O}+\mathrm{CaCO}_{3}+\mathrm{H}_{2} \mathrm{O}\right] \rightarrow \mathrm{Phl}+\mathrm{Di}+\mathrm{Fo}+\mathrm{CO}_{2} \uparrow
$$

$$
\text { (free fluid phase) [109]. }
$$

In systems without carbon dioxide, orthopyroxene was shown to react with melts of basic and intermediate compositions $\left(\mathrm{SiO}_{2}\right.$ from 45 to $\left.54 \mathrm{wt} \%\right)$ according to the following incongruent melting reaction:

$$
\begin{gathered}
\text { Opx }+ \text { melt } \rightarrow \mathrm{Ol}+\mathrm{Cpx}+\mathrm{SiO}_{2} \text { glass } \\
\left(1 \mathrm{~atm}, 1200^{\circ} \mathrm{C}\right)[110] .
\end{gathered}
$$

White et al. [111] reported enstatite macrocrysts with complex reaction rims in the Wesselton kimberlite sills, South Africa. The described enstatite rims are composed of four zones, i.e., zone 1 contains tiny anthophyllite crystals set in a matrix of phlogopite, further out are anthophyllite crystals in a matrix of $\mathrm{Cr}$-diopside, then elongate anthophyllites in a matrix of phlogopite, and the outermost zone is oxide-rich [111]. The reaction rims described in [111] appear to represent the more evolved variety in comparison with the coronas established here, since the enstatite macrocrysts from Wesselton are completely surrounded by kimberlite and could have been intensively resorbed, whereas in our sample the case is opposite, i.e., it is the enstatite that encloses CMI.

Based on the experimental and natural evidence, we posit that in our case, the rock-forming orthopyroxene reacted with the melt parental for the Udachnaya pipe via similar to the described above but more complicated reactions, since natural melts have more complex multicomponent compositions with respect to mixtures used in experiments. The widespread development of mica, a suite of K-Na amphiboles (see Table 1) and calcite in the sample suggests that the reacting melt was probably alkaline-rich carbonate melt as shown previously for the Udachnaya pipe [10,11,13,20,82,112]. Since carbonates are in subordinate amounts relative to other minerals inside the CMI, we assume that at pressure values $<2.5 \mathrm{GPa}$ in the system "orthopyroxene-infiltrating kimberlite melt" a decarbonization reaction occurred with the formation of a free carbon dioxide fluid phase (see Reactions (1)-(3), (6), (7)). This fluid phase was subsequently removed from the system. 
Simplified, the reaction between the orthopyroxene and kimberlite melt can be written as follows:

$$
\mathrm{Opx}+\mathrm{Na}-\mathrm{K}-\mathrm{CO}_{2} \text {-rich melt } \rightarrow \mathrm{Ol}+\mathrm{Mica}+\mathrm{Cpx}+\mathrm{K}-\mathrm{Na} \text {-rich Amp }+ \text { hybrid melt }+\mathrm{CO}_{2} \uparrow
$$

(see Figure 4).

Further, from the hybrid kimberlite melt that became more saturated with silica and lost a significant portion of carbon dioxide, the following association crystallized inside the melt inclusions and in the intergranular space of the rock:

$$
\begin{gathered}
\text { hybrid melt } \rightarrow \text { olivine }+ \text { mica }+ \text { ilmenite-group minerals }+ \\
\text { spinel-group minerals }+ \text { rutile }+ \text { perovskite }+ \text { calcite }+ \text { sulfides }+ \text { apatite } \pm \text { barite }
\end{gathered}
$$

(see Figure 3, Figure 5, Figure 6 and Table 1).

Note that this mineral association is typical for kimberlite groundmass worldwide.

\subsection{Stage 3: Late Hydrothermal Alterations}

The third event (Stage 3 in Table 1) comprises post-magmatic alterations of the xenolith under the influence of circulating hydrothermal fluids of external origin. We propose that during this stage originated all the minerals that are considered as "secondary" in the common sense, i.e., sheet silicates (serpentine and talc), $\mathrm{OH}$-chlorine-bearing minerals of iron (goethite, kuliginite, iowaite), hydrothermal variety of calcite (Cal2), magnetite (Spl6), possibly barite and dolomite.

Serpentine is a common component of the groundmass of kimberlites. Its origin in kimberlites, however, is still contentious. Two dominant models assume serpentine as being either late-stage magmatic mineral crystallizing from deuteric fluids (e.g., $[33,101,113]$ ) or hydrothermal mineral crystallizing from impregnating low-T fluids of external (non-magmatic) source, i.e., groundwaters (e.g., [114-116]). Both models accept that serpentine forms at least partly as a replacement product of olivine and other Mg-silicates. Other more complex models treat serpentine as a precipitate from Mg-Si gels [33,117] and mixed deuteric-external fluids [118].

We consider the lizardite studied here to have crystallized with a participation of an external hydrothermal fluid based on the following evidence. In partially altered (serpentinized) kimberlites of the Udachnaya-East mine, the association serpentine + iowaite + calcite \pm barite has been repeatedly established both within the kimberlite groundmass and among the hydrothermal associations in cavities and veins (e.g., [13,64]). However, in non-serpentinized ("fresh") kimberlites and mantle xenoliths from such kimberlites the association serpentine + talc + goethite + kuliginite + iowaite + barite has not been identified [10,11,16]. Moreover, all the minerals from this association are absent from daughter assemblages in melt inclusions (interpreted to represent the composition of evolving kimberlite melts during ascent) in rock-forming kimberlite minerals of the Udachnaya pipe $[13,19,80-82]$, as well as among daughter minerals in crystallized secondary melt inclusions (interpreted to reflect the composition of primitive kimberlite fluids) in olivine from the deepest xenoliths of sheared peridotites $[19,20,22]$.

In this regard, it is relevant to mention a study of large CMI consisting of a series of daughter minerals in clinopyroxene and olivine megacrysts from global kimberlites [23]. Such megacryst-hosted CMI might be considered as analogous to the CMI in orthopyroxene described here (however, without any links regarding PT conditions of their formation). According to [23], the polymineralic inclusions remained open system after crystallization due to connectivity with the kimberlite melt via network fractures/veins, which facilitated the percolation of external fluids. Owing to the impregnation of external fluids, the megacryst-hosted polymineralic inclusions appear to have exhibited intense degrees of alteration, which is manifested in the disappearance of water-soluble minerals and the formation of abundant serpentine, secondary calcite \pm barite [23]. 
The xenolith examined here comes from partially serpentinized kimberlites located at depths of 620-640 $\mathrm{m}$ in the Udachnaya-East open-pit mine. We postulate that the similar scenario as described in [23] is applicable to the CMI in orthopyroxene from this sample. The association of serpentine, talc, goethite, kuliginite, iowaite, secondary calcite, possibly barite and dolomite within the CMI and in intergranular space arose because of the reaction of the xenolith with external fluids derived from the sedimentary cover, which also partially serpentinized the kimberlites located at these depth levels. It is crucial to note that the euhedral olivine crystals inside the inclusions are not serpentinized, despite their occurrence within the serpentine matrix (Figure 3). This evidence unequivocally indicates that the olivine, although could have been partly serpentinized, was not the main contributor to serpentinization. However, it appears likely that the cryptocrystalline serpentine replaced a previously existed phase that had been highly susceptible to serpentinization. We suggest that this phase could have been Mg-Si glass formed as a reaction-induced product in the "orthopyroxene-kimberlite melt" system during quenching of hybridized kimberlite melt (see also experimental Reactions (3) and (8) in Section 4.3.4).

Hydroxides and hydroxyhalides of iron (goethite, kuliginite, iowaite) are well-established as minerals of low-temperature environments worldwide and their origin in the sample is undoubtedly related to post-emplacement hydrothermal circulation of groundwaters and brines, which invaded the kimberlite [64]. Goethite may partially result from oxidation of interstitial sulfides and magnetite, though its occurrence as reniform aggregates might indicate direct crystallization from a fluid. Magnetite is likely a by-product of serpentinization, as discussed previously (Section 4.3.3). Calcite occurring in close proximity to kuliginite and iowaite (Cal2) was probably formed from the same hydrothermal brines that deposited the hydroxyhalides. Barite in kimberlites is interpreted both as late-stage groundmass and hydrothermal mineral [33]; we have not obtained profound evidence in favor of any particular model, although the close association of barite with Al-poor alkali-rich amphiboles likely indicates its Stage 2-related nature. Dolomite has been recognized only in a single melt inclusion and hence is of probable hydrothermal derivation, although kimberlites containing igneous dolomite are also well-known $[33,119,120]$.

\subsection{Some Insights into the Origin of Redledgeite, Priderite and Ba-Na-Mg Phosphate}

The origin of redledgeite, priderite, and Ba-Na-Mg phosphate in the xenolith remains poorly constrained because of the lack of textural data, paucity of the minerals and insufficient knowledge concerning some of these minerals in literature. Below we make an attempt to resolve the issue by synthesizing literature data with the new insights obtained during this study.

Available evidence indicate that in deep-seated magmatic rocks hollandite-type titanates originate either as primary phases (such as groundmass priderite in lamproites) or as replacement (?) rims on earlier-formed oxide minerals [40,41,67]. Less common is postulated xenocrystic origin $[99,121]$. Redledgeite is either a very rare mineral that crystallizes under specific conditions, or very small, so its grains could have been easily overlooked during mantle studies, or both. As is known from its global occurrences, redledgeite seems to be relatively abundant in chromium ore deposits, where it forms euhedral crystals of significant size (several millimeters in length and even larger). Unfortunately, the origin of redledgeite is still not well constrained. On the basis of occurrence of redledgeite in thin veins in association with calcite and chromium chlorite in Saranov chromium deposit, Russia, Ivanov et al. [49] argued that redledgeite is of low-T hydrothermal origin, suggesting the mechanism of Ba derivation from wall-rock (schistic) barite, and $\mathrm{Ti}, \mathrm{Cr}, \mathrm{V}$ from diabase dikes and chromium spinel. A hydrothermal origin was also proposed for other Ba-characteristic mineral of the hollandite group, henrymeyerite from the Kovdor carbonatite, Russia [122].

On the textural and chemical grounds, we assume redledgeite from the mantle xenolith studied here to have crystallized from a late-stage portion of a hybridized kimberlite melt, which probably caused autometasomatic alteration of pre-existing minerals of kimberlitic affinity. It was not the main volume of the kimberlitic melt, because otherwise redledgeite would have been a typical accessory 
mineral in any Group 1 kimberlite, which is certainly not the case in view of its very rare findings. It was rather the same liquid enriched with a series of some silicate-incompatible elements, i.e., LILE, LREE, and $\mathrm{Nb}$ that induced the crystallization of $\mathrm{Na}-\mathrm{Nb}$-LREE-rich perovskite rims. The characteristic occurrence of redledgeite in intergrowths with and rims on other oxide minerals implies that it could have formed during a reaction between the involved metasomatizing liquid and $\mathrm{Cr}$-Ti-bearing pre-existing minerals. Given the very small thickness of rims, redledgeite easily inherited the necessary amount of chromium (perhaps along with titanium) from $\mathrm{Cr}$-bearing oxides such as $\mathrm{Cr}$-spinel, rutile, and ilmenite. The origin of redledgeite directly from the fluid seems less probable, but cannot be excluded taking into account the occurrence of individual redledgeite grains in the intergranular space (Figure 5d).

Priderite is a common accessory mineral of lamproites (e.g., [39-41]) and may occur in kimberlites as well (e.g., [99,123]). $\mathrm{K}^{\mathrm{A}}-\mathrm{Cr}^{\mathrm{B}}$-dominant mineral of the priderite subgroup (currently unapproved, [42]) has also been reported in kimberlite-borne xenoliths [17,67,124]. Priderite and "K-Cr-priderite" have been synthesized in high-pressure experiments $[125,126]$. In the studied sample, priderite definitely predates redledgeite, since the latter forms mantlings on the former (Figure 5e). On the other hand, priderite has not been found as inclusions in enstatite, so there are no evidence that priderite is coeval with the mantle metasomatic process responsible for the origin of YIHA and crichtonite-group minerals in the studied sample. We assume that priderite most likely replaced crichtonite-group mineral during the interaction of the xenolith with a Stage 2-related melt either at depth or during the ascent, although the exact reactions are currently not established. However, as in the case of redledgeite, it cannot be ruled out that priderite crystallized directly from a melt without the requirement to mantle a nucleation point composed of another titanate mineral.

In the ultrapotassic dyke Kvalöya, Norway, Ba-Na-Mg phosphate was identified as subhedral prismatic crystals set in a groundmass of lamproitic rock [60]. Similar to the Ba-Na-Mg phosphate studied here, the grains from Norway are associated with apatite and contain Sr as a minor component. The phosphate has been interpreted to originate as an accessory mineral from the primary lamproite melt rich in $\mathrm{Ba}, \mathrm{Ti}, \mathrm{Sr}, \mathrm{P}, \mathrm{Cl}$, and REE together with other uncommon minerals (baotite, Sr-rich apatite). Synthetic $\mathrm{Na} 2 \mathrm{BaMg}\left(\mathrm{PO}_{4}\right)_{2}$ was obtained at different temperatures $(673,873$, and $1173 \mathrm{~K})$ and is stable up to $1385 \mathrm{~K}$ [61]. In the xenolith studied here, Ba-Na-Mg phosphate was found in intergranular space, always in association with apatite and K-richterite. Therefore, we posit Ba-Na-Mg phosphate as being cognate to Stage 2 (kimberlite magmatism), probably to the late stages thereof.

Thus, priderite, redledgeite, and Ba-Na-Mg phosphate show a genetic affinity to the kimberlite magmatism rather than to the other distinguished mineralization events. We highlight that these minerals, as well as a suite of K-Na-rich amphiboles, are not typical to kimberlites in general, but it is probable that differentiation products of an evolved hybridized kimberlite melt charged with incompatible elements will crystallize such exotic phases at low modal proportions.

\section{Conclusions}

A remarkable diversity of epigenetic minerals in the examined orthopyroxenite assemblage is linked to the rich genetic history of the sample. The xenolith underwent a series of superimposed mineralization processes, which affected the rock within the lithospheric mantle, during kimberlite ascent and after emplacement in the crust. After the crystallization of high-temperature orthopyroxene and decomposition of its solid solution upon cooling, the orthopyroxenite was overprinted by at least three distinct superimposed processes (deep-sourced mantle metasomatism, infiltration of a kimberlite-related melt and late-stage hydrothermal alterations by external fluids), each of which was accompanied by crystallization of a characteristic series of minerals, later combined into a common mineral association. The major significance of the hydrothermal process is that the latter partly changed pre-existing mineral associations and also introduced minerals of crustal origin into the mantle-derived xenolith. 
The sample featured in this study provides an opportunity to unravel the multistage modification of a mantle-derived fragment by means of identifying a suite of superimposed minerals present in small $(<2 \mathrm{vol} \%)$ modal proportions. Our data indicate that epigenetic minerals may be widely distributed even in samples that are considered as pristine during preliminary mineralogical and petrographic observations. Given that some epigenetic minerals are major repositories of trace elements, their occurrence even in very low volumetric amounts should inevitably affect the whole-rock geochemistry. This possibility should be taken into account when interpreting whole-rock trace element compositions of mantle-derived samples.

Supplementary Materials: The following are available online at http://www.mdpi.com/2075-163X/10/3/264/s1. Table S1: EMP analyses of olivine. Table S2: Representative EMP analyses of phlogopite and tetraferriphlogopite. Table S3: Representative EMP analyses of amphibole-supergroup minerals. Table S4: Representative EMP analyses of ilmenite-group minerals. Table S5: Representative EMP analyses of spinel-group minerals. Table S6: Representative EMP analyses of LILE-bearing titanates. Table S7: Representative EMP analyses of sulfides in the crystallized melt inclusions.

Author Contributions: D.I.R. designed the concept of the manuscript and performed SEM/EMP analytical work; D.I.R. and A.V.G. wrote a major portion of the manuscript draft; T.A.A. conducted Raman spectroscopic study of minerals; A.V.G. and A.V.K. carried out the works in the field, sample preparation, and provided a portion of the analytical data; all the authors contributed to the discussion of the ideas presented and to the final version of the report. All authors have read and agreed to the published version of the manuscript.

Funding: Fieldworks in the Udachnaya open-pit mine, sample preparation, and Raman spectroscopic analyses were done within the IGM SB RAS state assignment project. The authors received additional funding from the Russian Science Foundation grant No. 18-77-10062 (SEM EDS data, BSE imagery, EMP analyses of minerals).

Acknowledgments: We appreciate the assistance of Elena Nigmatulina and Mikhail Khlestov (IGM SB RAS) in the collection of EMP data. Nikolai Gubanov and Dmitry Zedgenizov (IGM SB RAS) helped to acquire transmitted-light images. We thank two anonymous reviewers for their comments and suggestions that improved the quality of the report.

Conflicts of Interest: The authors declare no conflict of interest.

\section{References}

1. Jones, A.P. Upper-mantle enrichment by kimberlitic or carbonatitic magmatism. In Carbonatites; Bell, K., Ed.; Unwin Hyman: New South Wales, Australia, 1989; pp. 448-463.

2. Schmidberger, S.S.; Francis, D. Constraints on the trace element composition of the Archean mantle root beneath Somerset Island, Arctic Canada. J. Petrol. 2001, 42, 1095-1117. [CrossRef]

3. Kalfoun, F.; Ionov, D.; Merlet, C. HFSE residence and $\mathrm{Nb} / \mathrm{Ta}$ ratios in metasomatised, rutile-bearing mantle peridotites. Earth Planet. Sci. Lett. 2002, 199, 49-65. [CrossRef]

4. Grégoire, M.; Bell, D.R.; Le Roex, A.P. Garnet lherzolites from the Kaapvaal craton (South Africa): Trace element evidence for a metasomatic history. J. Petrol. 2003, 44, 629-657. [CrossRef]

5. Sharygin, I.S.; Golovin, A.V. Interstitial mineral assemblages in sheared garnet peridotites from Udachnaya-East kimberlite pipe, Siberian craton. In Proceedings of the International Kimberlite Conference, Gaborone, Botswana, 18-22 September 2017.

6. Marshintsev, V.K.; Migalkin, K.N.; Nikolaev, N.C.; Barashkov, Y.P. Unaltered kimberlite of the Udachnaya East pipe. Dokl. Acad. Nauk. SSSR 1976, 231, 961-964. (In Russian)

7. Zinchuk, N.N.; Spetsius, Z.V.; Zuenko, V.V.; Zuev, V.M. Udachnaya Kimberlite Pipe; Novosibirsk University: Novosibirsk, Russia, 1993; p. 147. (In Russian)

8. Kharkiv, A.D.; Zinchuk, N.N.; Kryuchkov, A.I. Primary Diamond Deposits of the World; Nedra: Moscow, Russia, 1998; p. 555. (In Russian)

9. Maas, R.; Kamenetsky, M.B.; Sobolev, A.V.; Kamenetsky, V.S.; Sobolev, N.V. Sr, Nd, and Pb isotope evidence for a mantle origin of alkali chlorides and carbonates in the Udachnaya kimberlite, Siberia. Geology 2005, 33, 549-552. [CrossRef]

10. Kamenetsky, V.S.; Kamenetsky, M.B.; Golovin, A.V.; Sharygin, V.V.; Maas, R. Ultrafresh salty kimberlite of the Udachnaya-East pipe (Yakutia, Russia): A petrological oddity or fortuitous discovery? Lithos 2012, 152, 173-186. [CrossRef] 
11. Kamenetsky, V.S.; Golovin, A.V.; Maas, R.; Giuliani, A.; Kamenetsky, M.B.; Weiss, Y. Towards a new model for kimberlite petrogenesis: Evidence from unaltered kimberlites and mantle minerals. Earth-Sci. Rev. 2014, 139, 145-167. [CrossRef]

12. Kitayama, Y.; Thomassot, E.; Galy, A.; Golovin, A.; Korsakov, A.; d'Eyrames, E.; Assayag, N.; Bouden, N.; Ionov, D. Co-magmatic sulfides and sulfates in the Udachnaya-East pipe (Siberia): A record of the redox state and isotopic composition of sulfur in kimberlites and their mantle sources. Chem. Geol. 2017, 455, 315-330. [CrossRef]

13. Abersteiner, A.; Kamenetsky, V.S.; Golovin, A.V.; Kamenetsky, M.; Goemann, K. Was crustal contamination involved in the formation of the serpentine-free Udachnaya-East kimberlite? New insights into parental melts, liquidus assemblage and effects of alteration. J. Petrol. 2018, 59, 1467-1492. [CrossRef]

14. Erlank, A.J.; Waters, F.G.; Hawkesworth, C.J.; Haggerty, S.E.; Allsopp, H.L.; Rickard, R.S.; Menzies, M.A. Evidence for mantle metasomatism in peridotite nodules from the Kimberley pipes, South Africa. In Mantle Metasomatism; Menzies, M.A., Hawkesworth, C.J., Eds.; Academic Press: London, UK, 1987; pp. 221-311.

15. Misra, K.C.; Anand, M.; Taylor, L.A.; Sobolev, N.V. Multi-stage metasomatism of diamondiferous eclogite xenoliths from the Udachnaya kimberlite pipe, Yakutia, Siberia. Contrib. Mineral. Petrol. 2004, 146, 696-714. [CrossRef]

16. Sharygin, I.S.; Golovin, A.V.; Pokhilenko, N.P. Djerfisherite in xenoliths of sheared peridotite in the Udachnaya-East pipe (Yakutia): Origin and relationship with kimberlitic magmatism. Russ. Geol. Geophys. 2012, 53, 247-261. [CrossRef]

17. Konzett, J.; Wirth, R.; Hauzenberger, C.; Whitehouse, M. Two episodes of fluid migration in the Kaapvaal Craton lithospheric mantle associated with Cretaceous kimberlite activity: Evidence from a harzburgite containing a unique assemblage of metasomatic zirconium-phases. Lithos 2013, 182, 165-184. [CrossRef]

18. Soltys, A.; Giuliani, A.; Phillips, D.; Kamenetsky, V.S.; Maas, R.; Woodhead, J.; Rodemann, T. In-situ assimilation of mantle minerals by kimberlitic magmas-Direct evidence from a garnet wehrlite xenolith entrained in the Bultfontein kimberlite (Kimberley, South Africa). Lithos 2016, 256, 182-196. [CrossRef]

19. Golovin, A.V.; Sharygin, I.S.; Korsakov, A.V. Origin of alkaline carbonates in kimberlites of the Siberian craton: Evidence from melt inclusions in mantle olivine of the Udachnaya-East pipe. Chem. Geol. 2017, 455, 357-375. [CrossRef]

20. Golovin, A.V.; Sharygin, I.S.; Kamenetsky, V.S.; Korsakov, A.V.; Yaxley, G.M. Alkali-carbonate melts from the base of cratonic lithospheric mantle: Links to kimberlites. Chem. Geol. 2018, 483, 261-274. [CrossRef]

21. Zedgenizov, D.A.; Ragozin, A.L.; Shatsky, V.S.; Griffin, W.L. Diamond formation during metasomatism of mantle eclogite by chloride-carbonate melt. Contrib. Mineral. Petrol. 2018, 173, 84-99. [CrossRef]

22. Golovin, A.V.; Sharygin, I.S.; Korsakov, A.V.; Kamenetsky, V.S.; Abersteiner, A. Can primitive kimberlite melts be alkali-carbonate liquids: Composition of the melt snapshots preserved in deepest mantle xenoliths. J. Raman Spectrosc. 2019, 1-19. [CrossRef]

23. Abersteiner, A.; Kamenetsky, V.S.; Goemann, K.; Golovin, A.V.; Sharygin, I.S.; Pearson, D.G.; Kamenetsky, M.; Gornova, M.A. Polymineralic inclusions in kimberlite-hosted megacrysts: Implications for kimberlite melt evolution. Lithos 2019, 336, 310-325. [CrossRef]

24. Bussweiler, Y. Polymineralic Inclusions in Megacrysts as Proxies for Kimberlite Melt Evolution-A Review. Minerals 2019, 9, 530-549. [CrossRef]

25. Lavrent'ev, Y.G.; Korolyuk, V.N.; Usova, L.V.; Nigmatulina, E.N. Electron probe microanalysis of rock-forming minerals with a JXA-8100 electron probe microanalyzer. Russ. Geol. Geophys. 2015, 56, 1428-1436. [CrossRef]

26. Lafuente, B.; Downs, R.; Yang, H.; Stone, N. The power of databases: The RRUFF project. In Highlights in Mineralogical Crystallography; Armbruster, T., Danisi, R.M., Eds.; De Gruyter: Berlin, Germany, 2015; pp. 1-30.

27. Rezvukhin, D.I.; Alifirova, T.A.; Korsakov, A.V.; Golovin, A.V. A new occurrence of yimengite-hawthorneite and crichtonite-group minerals in an orthopyroxenite from kimberlite: Implications for mantle metasomatism. Am. Mineral. J. Earth Planet. Mater. 2019, 104, 761-774. [CrossRef]

28. Hawthorne, F.C.; Oberti, R.; Harlow, G.E.; Maresch, W.V.; Martin, R.F.; Schumacher, J.C.; Welch, M.D. Nomenclature of the amphibole supergroup. Am. Mineral. 2012, 97, 2031-2048. [CrossRef]

29. Locock, A.J. An Excel spreadsheet to classify chemical analyses of amphiboles following the IMA 2012 recommendations. Comput. Geosci. 2014, 62, 1-11. [CrossRef]

30. Haggerty, S.E. Oxide mineralogy of the upper mantle. In Oxide Minerals: Petrologic and Magnetic Significance; Lindsley, D.H., Ed.; Mineralogical Society of America: Washington, DC, USA, 1991; Volume 25, pp. 355-416. 
31. Bosi, F.; Biagioni, C.; Pasero, M. Nomenclature and classification of the spinel supergroup. Eur. J. Mineral. 2018, 31, 183-192. [CrossRef]

32. Roeder, P.L.; Schulze, D.J. Crystallization of groundmass spinel in kimberlite. J. Petrol. 2008, 49, 1473-1495. [CrossRef]

33. Mitchell, R.H. Kimberlites: Mineralogy, Geochemistry and Petrology; Plenum Press: New York, NY, USA, 1986; p. 442.

34. Grey, I.E.; Lloyd, D.J.; White, J.S. The structure of crichtonite and its relationship to senaite. Am. Mineral. 1976, 61, 1203-1212.

35. Haggerty, S.E.; Smyth, J.R.; Erlank, A.J.; Rickard, R.S.; Danchin, R.V. Lindsleyite (Ba) and mathiasite (K): Two new chromium-titanates in the crichtonite series from the upper mantle. Am. Mineral. 1983, 68, 494-505.

36. Dong, Z.; Zhou, J.; Lu, Q.; Peng, Z.; Yimengite, K. K(Cr,Ti, Fe,Mg) ${ }_{12} \mathrm{O}_{19}-\mathrm{A}$ new mineral. Kexue Tongbao 1984, 29, 920-923.

37. Haggerty, S.E.; Grey, I.E.; Madsen, I.C.; Criddle, A.J.; Stanley, C.J.; Erlank, A.J. Hawthorneite, Ba $\left[\mathrm{Ti}_{3} \mathrm{Cr}_{4} \mathrm{Fe}_{4} \mathrm{Mg}\right] \mathrm{O}_{19}$ : A new metasomatic magnetoplumbite-type mineral from the upper mantle. Am. Mineral. 1989, 74, 668-675.

38. Nixon, P.H.; Condliffe, E. Yimengite of K-Ti metasomatic origin in kimberlitic rocks from Venezuela. Mineral. Mag. 1989, 53, 305-309. [CrossRef]

39. Norrish, K. Priderite, a new mineral from the leucite-lamproites of the west Kimberley area, Western Australia. Mineral. Mag. 1951, 29, 496-501. [CrossRef]

40. Mitchell, R.H.; Bergman, S.C. Petrology of Lamproites; Springer Science \& Business Media: Berlin, Germany, 1991; p. 447.

41. Jaques, A.L. Major and trace element variations in oxide and titanate minerals in the West Kimberley lamproites, Western Australia. Mineral. Petrol. 2016, 110, 159-197. [CrossRef]

42. Biagioni, C.; Capalbo, C.; Pasero, M. Nomenclature tunings in the hollandite supergroup. Eur. J. Mineral. 2013, 25, 85-90. [CrossRef]

43. Gordon, S.G.; Shannon, E.V. Chromrutile, a new mineral from California. Am. Mineral. 1928, 13, 69.

44. Strunz, H. Chromrutil von der Red Ledge mine ist kein Rutil. Redledgeite. Neues Jahrb. Für Mineral. Mon. 1961, 1961, 107-111.

45. Strunz, H. Redledgeit, eine $\mathrm{TIO}_{2}$-Einlagerungsstruktur analog Kryptomelan. Neues Jahrb. Für Mineral. Mon. 1963, 1963, 116-119.

46. Gatehouse, B.M.; Jones, G.C.; Pring, A.; Symes, R.F. The chemistry and structure of redledgeite. Mineral. Mag. 1986, 50, 709-715. [CrossRef]

47. Scott, J.D.; Peatfield, G.R. Mannardite $\left[\mathrm{Ba} \mathrm{H}_{2} \mathrm{O}\right]\left(\mathrm{Ti}_{6} \mathrm{~V}^{3+}{ }_{2}\right) \mathrm{O}_{16}$, a new mineral species, and new data on redledgeite. Can. Miner. 1986, 24, 55-66.

48. Foley, J.A.; Hughes, J.M.; Drexler, J.W. Redledgeite, $\mathrm{Ba}_{x}\left([\mathrm{Cr}, \mathrm{Fe}, \mathrm{V}]^{3+}{ }_{2 x} \mathrm{Ti}_{8-2 x}\right) \mathrm{O}_{16}$, the I4/m structure and elucidation of the sequence of tunnel Ba cations. Can. Mineral. 1997, 35, 1531-1534.

49. Ivanov, O.K.; Bushmakin, A.F.; Chukanov, N.V. Redledgeite from Saranov Chromite Deposits: The First Find in Russia. Trans. Russ. Acad. Sci. Earth Sci. Sect. 1996, 349, 775-778.

50. Schulze, D.J.; Helmstaedt, H.H.; Davis, D. Subducted Farallon Plate Carries Water for Hydration Above the Flat Slab and Deep into the Mantle: Evidence from the Navajo Volcanic Field HP and UHP Xenolith Suite. In Proceedings of the AGU Fall Meeting Abstracts, San Francisco, CA, USA, 15-19 December 2014.

51. Naemura, K.; Shimizu, I.; Svojtka, M.; Hirajima, T. Accessory priderite and burbankite in multiphase solid inclusions in the orogenic garnet peridotite from the Bohemian Massif, Czech Republic. J. Mineral. Petrol. Sci. 2015, 110, 20-28. [CrossRef]

52. Tollo, R.P.; Haggerty, S.E. Nb-Cr-rutile in the Orapa kimberlite pipe, Botswana. Can. Mineral. 1987, 25, 251-264.

53. Meinhold, G. Rutile and its applications in earth sciences. Earth-Sci. Rev. 2010, 102, 1-28. [CrossRef]

54. Rezvukhin, D.I.; Malkovets, V.G.; Sharygin, I.S.; Kuzmin, D.V.; Litasov, K.D.; Gibsher, A.A.; Pokhilenko, N.P.; Sobolev, N.V. Inclusions of $\mathrm{Cr}$-and $\mathrm{Cr}-\mathrm{Nb}$-Rutile in pyropes from the Internatsionalnaya kimberlite pipe, Yakutia. Dokl. Earth Sci. 2016, 466, 173-176. [CrossRef]

55. Malkovets, V.G.; Rezvukhin, D.I.; Belousova, E.A.; Griffin, W.L.; Sharygin, I.S.; Tretiakova, I.G.; Gibsher, A.A.; O'Reilly, S.Y.; Kuzmin, D.V.; Litasov, K.D.; et al. Cr-rich rutile: A powerful tool for diamond exploration. Lithos 2016, 265, 304-311. [CrossRef] 
56. Post, J.E.; Von Dreele, R.B.; Buseck, P.R. Symmetry and cation displacements in hollandites: Structure refinements of hollandite, cryptomelane and priderite. Acta Crystallogr. Sect. B 1982, 38, 1056-1065. [CrossRef]

57. Szymanski, J.T. The crystal structure of mannardite, a new hydrated cryptomelane-group (hollandite) mineral with a doubled short axis. Can. Mineral. 1986, 24, 67-78.

58. Abersteiner, A.; Kamenetsky, V.S.; Goemann, K.; Golovin, A.V.; Sharygin, I.S.; Giuliani, A.; Rodemann, T.; Spetsius, Z.V.; Kamenetsky, M. Djerfisherite in kimberlites and their xenoliths: Implications for kimberlite melt evolution. Contrib. Mineral. Petrol. 2019, 174, 8-29. [CrossRef]

59. O'Reilly, S.Y.; Griffin, W. Apatite in the mantle: Implications for metasomatic processes and high heat production in Phanerozoic mantle. Lithos 2000, 53, 217-232. [CrossRef]

60. Zozulya, D.R.; Savchenko, E.E.; Kullerud, K.; Ravna, E.K.; Lyalina, L.M. Unique accessory Ti-Ba-P mineralization in the Kvalöya ultrapotassic dike, Northern Norway. Geol. Ore Depos. 2010, 52, 843-851. [CrossRef]

61. Boukhris, A.; Hidouri, M.; Glorieux, B.; Amara, M.B. $\mathrm{Na}_{2} \mathrm{BaMg}\left(\mathrm{PO}_{4}\right)_{2}$ : Synthesis, crystal structure and europium photoluminescence properties. J. Rare Earths 2013, 31, 849-856. [CrossRef]

62. Fuchs, L.H.; Olsen, E.; Henderson, E.P. On the occurrence of brianite and panethite, two new phosphate minerals from the Dayton meteorite. Geochim. Cosmochim. Acta 1967, 31, 1711-1719. [CrossRef]

63. Nishio-Hamane, D.; Minakawa, T.; Okada, H. Iwateite, $\mathrm{Na}_{2} \mathrm{BaMn}\left(\mathrm{PO}_{4}\right)_{2}$, a new mineral from the Tanohata mine, Iwate Prefecture, Japan. J. Mineral. Petrol. Sci. 2014, 109, 34-37. [CrossRef]

64. Mikhailenko, D.S.; Korsakov, A.V.; Rashchenko, S.V.; Seryotkin, Y.V.; Belakovskiy, D.I.; Golovin, A.V. Kuliginite, a new hydroxychloride mineral from the Udachnaya kimberlite pipe, Yakutia: Implications for low-temperature hydrothermal alteration of the kimberlites. Am. Mineral. J. Earth Planet. Mater. 2018, 103, 1435-1444. [CrossRef]

65. Gibson, S.A. On the nature and origin of garnet in highly-refractory Archean lithospheric mantle: Constraints from garnet exsolved in Kaapvaal craton orthopyroxenes. Mineral. Mag. 2017, 81, 781-809. [CrossRef]

66. Tomlinson, E.L.; Kamber, B.S.; Hoare, B.C.; Stead, C.V.; Ildefonse, B. An exsolution origin for Archean mantle garnet. Geology 2017, 46, 123-126. [CrossRef]

67. Jones, A.P.; Smith, J.V.; Dawson, J.B. Mantle metasomatism in 14 veined peridotites from Bultfontein mine, South Africa. J. Geol. 1982, 90, 435-453. [CrossRef]

68. Haggerty, S.E. The mineral chemistry of new titanates from the Jagersfontein kimberlite, South Africa-Implications for metasomatism in the upper mantle. Geochim. Cosmochim. Acta 1983, 47, 1833-1854. [CrossRef]

69. Wang, L.; Essene, E.J.; Zhang, Y. Mineral inclusions in pyrope crystals from Garnet Ridge, Arizona, USA: Implications for processes in the upper mantle. Contrib. Mineral. Petrol. 1999, 135, 164-178. [CrossRef]

70. Almeida, V.; Janasi, V.; Svisero, D.; Nannini, F. Mathiasite-loveringite and priderite in mantle xenoliths from the Alto Paranaíba Igneous Province, Brazil: Genesis and constraints on mantle metasomatism. Cent. Eur. J. Geosci. 2014, 6, 614-632. [CrossRef]

71. Griffin, W.L.; Pearson, N.J.; Andersen, T.; Jackson, S.E.; O'Reilly, S.Y.; Zhang, M. Sources of cratonic metasomatic fluids: In situ LA-MC-ICPMS analysis of $\mathrm{Sr}, \mathrm{Nd}, \mathrm{Hf}$ and $\mathrm{Pb}$ isotopes in LIMA from the Jagersfontein kimberlite. Am. J. Sci. 2014, 314, 435-461. [CrossRef]

72. Giuliani, A.; Phillips, D.; Maas, R.; Woodhead, J.D.; Kendrick, M.A.; Greig, A.; Armstrong, R.A.; Chew, D.; Kamenetsky, V.S.; Fiorentini, M.L. LIMA U-Pb ages link lithospheric mantle metasomatism to Karoo magmatism beneath the Kimberley region, South Africa. Earth Planet. Sci. Lett. 2014, 401, 132-147. [CrossRef]

73. Rezvukhin, D.I.; Malkovets, V.G.; Sharygin, I.S.; Tretiakova, I.G.; Griffin, W.L.; O'Reilly, S.Y. Inclusions of crichtonite-group minerals in Cr-pyropes from the Internatsionalnaya kimberlite pipe, Siberian Craton: Crystal chemistry, parageneses and relationships to mantle metasomatism. Lithos 2018, 308, 181-195. [CrossRef]

74. Haggerty, S.E. Mantle metasomes and the kinship between carbonatites and kimberlites. In Carbonatites; Bell, K., Ed.; Unwin Hyman: New South Wales, Australia, 1989; pp. 546-560.

75. Kinny, P.D.; Griffin, B.J.; Heaman, L.M.; Brakhfogel, F.F.; Spetsius, Z.V. SHRIMP U-Pb ages of perovskite from Yakutian kimberlites. Russ. Geol. Geophys. 1997, 38, 91-99. 
76. Irving, A.J.; Wyllie, P.J. Subsolidus and melting relationships for calcite, magnesite and the join $\mathrm{CaCO}_{3}-\mathrm{MgCO}_{3}$ to 36 kbar. Geochim. Cosmochim. Acta 1975, 39, 35-53. [CrossRef]

77. Sharygin, V.V.; Golovin, A.V.; Pokhilenko, N.P.; Sobolev, N.V. Djerfisherite in unaltered kimberlites of the Udachnaya-East pipe, Yakutia. Dokl. Earth Sci. 2003, 390, 554-557.

78. Sharygin, V.V.; Golovin, A.V.; Pokhilenko, N.P.; Kamenetsky, V.S. Djerfisherite in the Udachnaya-East pipe kimberlites (Sakha-Yakutia, Russia): Paragenesis, composition and origin. Eur. J. Mineral. 2007, 19, 51-63. [CrossRef]

79. Golovin, A.V.; Goryainov, S.V.; Kokh, S.N.; Sharygin, I.S.; Rashchenko, S.V.; Kokh, K.A.; Sokol, E.V.; Devyatiyarova, A.S. The application of Raman spectroscopy to djerfisherite identification. J. Raman Spectrosc. 2017, 48, 1574-1582. [CrossRef]

80. Golovin, A.V.; Sharygin, V.V.; Pokhilenko, N.P.; Mal'kovets, V.G.; Kolesov, B.A.; Sobolev, N.V. Secondary melt inclusions in olivine from unaltered kimberlites of the Udachnaya-East pipe, Yakutia. Dokl. Earth Sci. 2003, 388, 93-96.

81. Golovin, A.V.; Sharygin, V.V.; Pokhilenko, N.P. Melt inclusions in olivine phenocrysts in unaltered kimberlites from the Udachnaya-East pipe, Yakutia: Some aspects of kimberlite magma evolution during late crystallization stages. Petrology 2007, 15, 168-183. [CrossRef]

82. Kamenetsky, M.B.; Sobolev, A.V.; Kamenetsky, V.S.; Maas, R.; Danyushevsky, L.V.; Thomas, R.; Pokhilenko, N.P.; Sobolev, N.V. Kimberlite melts rich in alkali chlorides and carbonates: A potent metasomatic agent in the mantle. Geology 2004, 32, 845-848. [CrossRef]

83. Sharygin, I.S.; Litasov, K.D.; Sharygin, V.V.; Shatskiy, A.; Ohtani, E. Genesis of djerfisherite in kimberlite-hosted mantle xenoliths. In Proceedings of the Goldschmidt Conference, Yokohama, Japan, 26 June-1 July 2016. Abstract No. 2812.

84. Giuliani, A.; Phillips, D.; Kamenetsky, V.S.; Goemann, K. Constraints on kimberlite ascent mechanisms revealed by phlogopite compositions in kimberlites and mantle xenoliths. Lithos 2016, 240, 189-201. [CrossRef]

85. Sobolev, N.V.; Logvinova, A.M.; Zedgenizov, D.A.; Pokhilenko, N.P.; Malygina, E.V.; Kuzmin, D.V.; Sobolev, A.V. Petrogenetic significance of minor elements in olivines from diamonds and peridotite xenoliths from kimberlites of Yakutia. Lithos 2009, 112, 701-713. [CrossRef]

86. Doucet, L.S.; Ionov, D.A.; Golovin, A.V.; Pokhilenko, N.P. Depth, degrees and tectonic settings of mantle melting during craton formation: Inferences from major and trace element compositions of spinel harzburgite xenoliths from the Udachnaya kimberlite, central Siberia. Earth Planet. Sci. Lett. 2012, 359, 206-218. [CrossRef]

87. Doucet, L.S.; Ionov, D.A.; Golovin, A.V. The origin of coarse garnet peridotites in cratonic lithosphere: New data on xenoliths from the Udachnaya kimberlite, central Siberia. Contrib. Mineral. Petrol. 2013, 165, 1225-1242. [CrossRef]

88. Agashev, A.M.; Ionov, D.A.; Pokhilenko, N.P.; Golovin, A.V.; Cherepanova, Y.; Sharygin, I.S. Metasomatism in lithospheric mantle roots: Constraints from whole-rock and mineral chemical composition of deformed peridotite xenoliths from kimberlite pipe Udachnaya. Lithos 2013, 160, 201-215. [CrossRef]

89. Ionov, D.A.; Doucet, L.S.; von Strandmann, P.A.P.; Golovin, A.V.; Korsakov, A.V. Links between deformation, chemical enrichments and Li-isotope compositions in the lithospheric mantle of the central Siberian craton. Chem. Geol. 2017, 475, 105-121. [CrossRef]

90. Kamenetsky, V.S.; Kamenetsky, M.B.; Sobolev, A.V.; Golovin, A.V.; Demouchy, S.; Faure, K.; Sharygin, V.V.; Kuzmin, D.V. Olivine in the Udachnaya-East kimberlite (Yakutia, Russia): Types, compositions and origins. J. Petrol. 2008, 49, 823-839. [CrossRef]

91. Sobolev, N.V.; Sobolev, A.V.; Tomilenko, A.A.; Kovyazin, S.V.; Batanova, V.G.; Kuz'min, D.V. Paragenesis and complex zoning of olivine macrocrysts from unaltered kimberlite of the Udachnaya-East pipe, Yakutia: Relationship with the kimberlite formation conditions and evolution. Russ. Geol. Geophys. 2015, 56, 260-279. [CrossRef]

92. Bussweiler, Y.; Foley, S.F.; Prelević, D.; Jacob, D.E. The olivine macrocryst problem: New insights from minor and trace element compositions of olivine from Lac de Gras kimberlites, Canada. Lithos 2015, 220, 238-252. [CrossRef]

93. De Hoog, J.C.; Gall, L.; Cornell, D.H. Trace-element geochemistry of mantle olivine and application to mantle petrogenesis and geothermobarometry. Chem. Geol. 2010, 270, 196-215. [CrossRef] 
94. Pilbeam, L.H.; Nielsen, T.; Waight, T.E. Digestion fractional crystallization (DFC): An important process in the genesis of kimberlites. Evidence from olivine in the Majuagaa kimberlite, southern West Greenland. J. Petrol. 2013, 54, 1399-1425. [CrossRef]

95. Tompkins, L.A.; Haggerty, S.E. Groundmass oxide minerals in the Koidu kimberlite dikes, Sierra Leone, West Africa. Contrib. Mineral. Petrol. 1985, 91, 245-263. [CrossRef]

96. Castillo-Oliver, M.; Melgarejo, J.C.; Galí, S.; Pervov, V.; Gonçalves, A.O.; Griffin, W.L.; Pearson, N.J.; O'Reilly, S.Y. Use and misuse of Mg-and Mn-rich ilmenite in diamond exploration: A petrographic and trace element approach. Lithos 2017, 292, 348-363. [CrossRef]

97. Chakhmouradian, A.R.; Mitchell, R.H. Occurrence, alteration patterns and compositional variation of perovskite in kimberlites. Can. Mineral. 2000, 38, 975-994. [CrossRef]

98. Chakhmouradian, A.R.; Reguir, E.P.; Kamenetsky, V.S.; Sharygin, V.V.; Golovin, A.V. Trace-element partitioning in perovskite: Implications for the geochemistry of kimberlites and other mantle-derived undersaturated rocks. Chem. Geol. 2013, 353, 112-131. [CrossRef]

99. Chakhmouradian, A.R.; Mitchell, R.H. Three compositional varieties of perovskite from kimberlites of the Lac de Gras field (Northwest Territories, Canada). Mineral. Mag. 2001, 65, 133-148. [CrossRef]

100. Sharygin, I.S.; Litasov, K.D.; Shatskiy, A.; Safonov, O.G.; Golovin, A.V.; Ohtani, E.; Pokhilenko, N.P. Experimental constraints on orthopyroxene dissolution in alkali-carbonate melts in the lithospheric mantle: Implications for kimberlite melt composition and magma ascent. Chem. Geol. 2017, 455, 44-56. [CrossRef]

101. Mitchell, R.H. Petrology of hypabyssal kimberlites: Relevance to primary magma compositions. J. Volcanol. Geotherm. Res. 2008, 174, 1-8. [CrossRef]

102. Brett, R.C.; Russell, J.K.; Moss, S. Origin of olivine in kimberlite: Phenocryst or impostor? Lithos 2009, 112, 201-212. [CrossRef]

103. Kamenetsky, V.S.; Kamenetsky, M.B.; Sobolev, A.V.; Golovin, A.V.; Sharygin, V.V.; Pokhilenko, N.P.; Sobolev, N.V. Can pyroxenes be liquidus minerals in the kimberlite magma? Lithos 2009, 112, $213-222$. [CrossRef]

104. Bowen, N.L.; Andersen, O. The binary system $\mathrm{MgO}-S i O_{2}$. Am. J. Sci. 1914, 37, 487-500. [CrossRef]

105. Wyllie, P.J.; Huang, W.L. Peridotite, kimberlite, and carbonatite explained in the system $\mathrm{CaO}-\mathrm{MgO}-\mathrm{SiO}_{2}-\mathrm{CO}_{2}$. Geology 1975, 3, 621-624. [CrossRef]

106. Thibault, Y.; Edgar, A.D.; Lloyd, F.E. Experimental investigation of melts from a carbonated phlogopite lherzolite: Implications for metasomatism in the continental lithospheric mantle. Am. Mineral. 1992, 77, 784-794.

107. Russell, J.K.; Porritt, L.A.; Lavallee, Y.; Dingwell, D.B. Kimberlite ascent by assimilation-fuelled buoyancy. Nature 2012, 481, 352-356. [CrossRef] [PubMed]

108. Kamenetsky, V.S.; Yaxley, G.M. Carbonate-silicate liquid immiscibility in the mantle propels kimberlite magma ascent. Geochim. Cosmochim. Acta 2015, 158, 48-56. [CrossRef]

109. Safonov, O.; Butvina, V.; Limanov, E. Phlogopite-Forming Reactions as Indicators of Metasomatism in the Lithospheric Mantle. Minerals 2019, 9, 685. [CrossRef]

110. Shaw, C.S.; Thibault, Y.; Edgar, A.D.; Lloyd, F.E. Mechanisms of orthopyroxene dissolution in silica-undersaturated melts at 1 atmosphere and implications for the origin of silica-rich glass in mantle xenoliths. Contrib. Mineral. Petrol. 1998, 132, 354-370. [CrossRef]

111. White, J.L.; Sparks, R.S.J.; Bailey, K.; Barnett, W.P.; Field, M.; Windsor, L. Kimberlite sills and dykes associated with the Wesselton kimberlite pipe, Kimberley, South Africa. S. Afr. J. Geol. 2012, 115, 1-32. [CrossRef]

112. Kamenetsky, V.S.; Kamenetsky, M.B.; Sharygin, V.V.; Faure, K.; Golovin, A.V. Chloride and carbonate immiscible liquids at the closure of the kimberlite magma evolution (Udachnaya-East kimberlite, Siberia). Chem. Geol. 2007, 237, 384-400. [CrossRef]

113. Mitchell, R.H. Paragenesis and oxygen isotopic studies of serpentine in kimberlite. In Proceedings of the 10th International Kimberlite Conference; Springer: Berlin, Germany, 2013; pp. 1-12.

114. Stripp, G.R.; Field, M.; Schumacher, J.C.; Sparks, R.S.J.; Cressey, G. Post-emplacement serpentinization and related hydrothermal metamorphism in a kimberlite from Venetia, South Africa. J. Metamorph. Geol. 2006, 24, 515-534. [CrossRef]

115. Sparks, R.S.J. Kimberlite volcanism. Annu. Rev. Earth Planet. Sci. 2013, 41, 497-528. [CrossRef]

116. Afanasyev, A.A.; Melnik, O.; Porritt, L.; Schumacher, J.C.; Sparks, R.S.J. Hydrothermal alteration of kimberlite by convective flows of external water. Contrib. Mineral. Petrol. 2014, 168, 1038-1054. [CrossRef] 
117. Devouard, B.; Baronnet, A.; Van Tendeloo, G.; Amelinckx, S. First evidence of synthetic polygonal serpentines. Eur. J. Mineral. 1997, 9, 539-546. [CrossRef]

118. Giuliani, A.; Soltys, A.; Phillips, D.; Kamenetsky, V.S.; Maas, R.; Goemann, K.; Woodhead, J.D.; Drysdale, R.N.; Griffin, W.L. The final stages of kimberlite petrogenesis: Petrography, mineral chemistry, melt inclusions and Sr-CO isotope geochemistry of the Bultfontein kimberlite (Kimberley, South Africa). Chem. Geol. 2017, 455, 342-356. [CrossRef]

119. Armstrong, J.P.; Wilson, M.; Barnett, R.L.; Nowicki, T.; Kjarsgaard, B.A. Mineralogy of primary carbonate-bearing hypabyssal kimberlite, Lac de Gras, Slave Province, Northwest Territories, Canada. Lithos 2004, 76, 415-433. [CrossRef]

120. Zurevinski, S.E.; Mitchell, R.H. Highly evolved hypabyssal kimberlite sills from Wemindji, Quebec, Canada: Insights into the process of flow differentiation in kimberlite magmas. Contrib. Mineral. Petrol. 2011, 161, 765-776. [CrossRef]

121. Mitchell, R.H.; Meyer, H.O.A. Niobian K-Ba-V titanates from micaceous kimberlite, Star mine, Orange Free State, South Africa. Mineral. Mag. 1989, 53, 451-456. [CrossRef]

122. Mitchell, R.H.; Yakovenchuk, V.N.; Chakhmouradian, A.R.; Burns, P.C.; Pakhomovsky, Y.A. Henrymeyerite, a new hollandite-type Ba-Fe titanate from the Kovdor Complex, Russia. Can. Mineral. 2000, 38, 617-626. [CrossRef]

123. Kamenetsky, V.S.; Belousova, E.A.; Giuliani, A.; Kamenetsky, M.B.; Goemann, K.; Griffin, W.L. Chemical abrasion of zircon and ilmenite megacrysts in the Monastery kimberlite: Implications for the composition of kimberlite melts. Chem. Geol. 2014, 383, 76-85. [CrossRef]

124. Zhou, H.; Lu, Q. K-Cr priderite-A new facies of the priderite series found in Mengying kimberlite, Shandong province-II. Ti, Cr, Fe oxide minerals containing LIL elements in the upper mantle Acta Mineral. Sin. 1994, 13, 234-240.

125. Foley, S.; Höfer, H.; Brey, G. High-pressure synthesis of priderite and members of the lindsleyite-mathiasite and hawthorneite-yimengite series. Contrib. Mineral. Petrol. 1994, 117, 164-174. [CrossRef]

126. Butvina, V.G.; Vorobey, S.S.; Safonov, O.G.; Varlamov, D.A.; Bondarenko, G.V.; Shapovalov, Y.B. Experimental study of formation of chromian priderite and yimengite as products of modal mantle metasomatism. Dokl. Earth Sci. 2019, 486, 709-713. [CrossRef] 